\title{
Re-assessing the Genocide of Kurdish Alevis in Dersim, 1937-38
}

Dilşa Deniz

University of California

Follow this and additional works at: https://digitalcommons.usf.edu/gsp

\section{Recommended Citation}

Deniz, Dilşa (2020) "Re-assessing the Genocide of Kurdish Alevis in Dersim, 1937-38," Genocide Studies and Prevention: An International Journal: Vol. 14: Iss. 2: 20-43.

DOI:

https://doi.org/10.5038/1911-9933.14.2.1728

Available at: https://digitalcommons.usf.edu/gsp/vol14/iss2/5

This Articles is brought to you for free and open access by the Open Access Journals at Digital Commons @ University of South Florida. It has been accepted for inclusion in Genocide Studies and Prevention: An International Journal by an authorized editor of Digital Commons @ University of South Florida. For more information, please contact digitalcommons@usf.edu. 


\section{Re-assessing the Genocide of Kurdish Alevis in Dersim, 1937-38}

\section{Acknowledgements}

I would like to thank my friend and colleague, Nancy Postero, for suggesting the title for this article, and for reading the article and providing me with great feedback. I would also like to thank the Scholar Rescue Fund (IIE-SRF) and Scholar at Risk Network (SAR) for their great support. Thanks to Leanne W. Green and Morgen A. Chalmers for their English language editing. 


\title{
Re-assessing the Genocide of Kurdish Alevis in Dersim, 1937-38
}

\author{
Dilşa Deniz \\ University of California \\ San Diego, California, USA
}

\section{Introduction}

In the process of nation-state formation, many governments have engaged in homogenization policies in order to establish political, social, and cultural hegemony. The Turkish state's intensive efforts to Turkify and Islamize Anatolia represent a prime example of this phenomenon. Using census data to estimate casualties, I argue that the events of 1937-38, in the province that was then called Dersim, in Eastern Turkey, should be classified as a genocide. Although state documents of that period remain inaccessible, we know that military operations continued for more than a period of two years, employing a large number of army troops. ${ }^{1}$ They used militaristic technology including poisonous gas and heavy bombardments, ${ }^{2}$ and they destroyed the living conditions of Alevi Kurds of Dersim through the burning of forests, fields, and villages. ${ }^{3}$ Children were forcibly removed from their natal families. ${ }^{4}$ While the numbers of those killed still remain lost in history, I examine archival records, memoirs, and first-hand accounts to arrive at estimated figures. These make it clear that the actions of the Turkish military led to mass killings and had a devastating impact on survivors, both mentally and physically.

\section{Dersim: The Center of Kurdish Alevis}

As a strategic and unique highland characterized by deep valleys, forests, and rivers, Dersim served as a true refuge for Kurdish Alevis. ${ }^{5}$ Since the period of the Ottoman Empire to the present, Dersim has "stood markedly at odds with the politico-cultural landscape of 1930s Turkey," ${ }^{6}$ for its non-Turkish ethnic character and, more importantly, for the predominance of the "heretic religion" of the Alevis, who represented for the Turkish state a population that "needed to be corrected and their savagery to be dispel[led]." ${ }^{\prime 7}$ As such, this article discusses the Dersim genocide as part of the Turkish nation state's homogenization policies and, particularly those that took place inside its borders soon after its foundation between 1920-1923. The policies implemented since 1930-especially those that followed the Iskan Kanunu/Resettlement Law of 1934 (hereafter Resettlement Law $)^{8}$ - laid the foundations for the systematic, continual, and violent Turkification and Islamization of Anatolia. Dersim was targeted soon after by the Kemalist cadres because of its inhabitants' religion and Kurdish ethnic background.

${ }^{1}$ Kaynak Yayınları, Genelkurmay Belgelerinde Kürt İsyanları II (Istanbul: Kaynak Yayınları, 2011), 109-132; Bilal N. Şimşir, Ingiliz Belgeleriyle Türkiye'de Kürt Sorunu (1924-1938): Şeyh Sait, Ağrı, ve Dersim Ayaklanmaları (Ankara: Türk Tarih Kurumu Basimevi, 1991), 301; Kendal, "Kurdistan in Turkey," in People Without A Country, The Kurds and Kurdistan, ed. Gerard Chaliand (London: Zed, 1980), 67.

2 Dersim Gazetesi, “Zehirli Gazlar Nazi Almanyası'ndan Alınmış!,” Dersim Gazetesi, May 15, 2019, accessed July 8, 2020, http://dersimgazetesi.net/zehirli-gazlar-almanyadan-bombardiman-ucaklari-amerikadan-alinmis/; "Dersim Katliamı Ile Ilgili Yeni Belgeler Ortaya Çıktı: Dersim'de Nazi Gazları," Pirha, May 11, 2019, accessed July 7, 2020, https://www. pirha.net/dersim-katliami-ile-ilgili-yeni-belgeler-ortaya-cikti-dersimde-nazi-gazlari-171973.html/11/05/2019/; Nuri Dersimi, Kürdistan Tarihinde Dersim (Diyarbakır: Dilan, 1991), 301; Kendal, Kurdistan, 67.

${ }^{3}$ Kaynak, Genelkurmay Belgeleri II, 202; Faik Bulut, Dersim Raporları (Istanbul: Evrensel Basım Yayım, 2009), 341; Mahmut Akyürekli, Dersim Kürt Tedibi 1937-1938 (Istanbul: Kitap Yayinevi, 2012), 159.

${ }^{4}$ Nezahat Gündoğan and Kazım Gündoğan, Dersim'in Kayıp Kızları (Istanbul: İletişim, 2016), 17; Özgür Fındık, Kara Vagon, Dersim-Kırım ve Sürgün (Istanbul: Fam, 2012), 215; Hüsnü Gürbey and Mahsuni Gül, "Dersim'de Nazi Gazı," Rojnameya Newroz, May 16, 2019, accessed April 4, 2020, http://rojnameyanewroz2.com/dersimde-nazi-gazi-h-gurbeym-gul-14583.html.

${ }^{5}$ The region's altitude averages between 1,000 and 1,500 meters in inhabited areas and exceeds 3,000 meters in the high and rocky mountains.

${ }^{6}$ Hans-Lukas Kieser, “Dersim Massacre, 1937-1938," Online Encyclopedia of Mass Violence, July 27, 2011, accessed April 5, 2019, https://www.sciencespo.fr/mass-violence-war-massacre-resistance/en/document/dersim-massacre-1937-1938.

${ }^{7}$ Barış Ünlü, "Kürdistan/Türkiye ve Cezayir/Fransa: Sömürge Yöntemleri, Şiddet ve Entellektüeller," in Türkiye'de Siyasal Şiddetin Boyutlarl, ed. Güney Çeğin and İbrahim Şirin (Istanbul: İletişim, 2014), 425.

${ }^{8}$ Iskân Kanunu (Turkish Resettlement Law) of 1934 (Law No. 2510, June 21, 1934), (Rep. of Turkey), accessed July 7, 2020, http://www.resmigazete.gov.tr/arsiv/2733.pdf. 
Hamit Bozarslan, however, made it clear that the official ideology of Turkey was not Kemalism but rather Turkish Islamic Synthesis (TIS), an ideology whose roots can be traced back to the ideas expressed by Ziya Gökalp between 1910 and 1920. The TIS in its current form was developed by a club of right-wing intellectuals (Aydinlar Ocă̆g/Home of Intellectuals) in the 1970s and was subsequently adopted by the generals of the 1980s coup. ${ }^{9}$ Henry Barkey observed that the primary objective of state policy at that time was the assimilation of the Kurds. This state assimilation policy contained both repressive and inclusionary dimensions, with the latter applicable only to those who accepted the dominant Turkish identity. ${ }^{10}$ In 1934, the state adopted the Resettlement Law to establish a juridical basis for resettling the country's population according to cultural and linguistic groupings. As such, the state referred to the regions around Dersim as East and South East Anatolia, refusing to identify it as Kurdistan. Furthermore, its residents were referred to euphemistically as the population whose mother tongue was not Turkish and who should therefore be forced to migrate for purposes of assimilation, ${ }^{11}$ in accordance with the Islahat/reforms. To promote demographic change in Anatolia and Kurdistan in particular, the non-Turkish areas were to be repopulated through the state-sponsored resettlement of Turkish immigrants in order to trigger the subsequent assimilation of the non-Turkish population. Accordingly, the country was divided on June 14, 1934 into three zones:

Zone 1: The areas desired to increase the density of the culturally Turkish population.

Zone 2: The areas deposited for the transference and resettlement of the populations that desired to be assimilated into Turkish culture.

Zone 3: The areas that had been decided to be evacuated for the health, economic, cultural, political, military and discipline reasons and where resettlement was prohibited. ${ }^{12}$

Dersim was in the third zone, which meant it was to be evacuated and closed to inhabitants. For that reason, in 1936, the Fourth Inspectorate was established and lieutenant general Abdullah Alpdoğan "was granted the highest judicial and administrative powers to facilitate the implementation of the reform program"13 in Dersim. Through this program, non-Turks and non-Muslims would be removed from where they collectively resided and relocated to zones in which they could be assimilated.

The Resettlement Law was used in conjunction with Takrir-i Sükun Kanunu (the Law of the Maintenance of Order),${ }^{14}$ another important legal tool of that period. To promote Turkification, state policies sought to rearrange the non-Turkish population such that it would not exceed ten percent of the Turkish population in any one location. Thus, from 1930s on, the state increased these operations, which reached their peak in Dersim in 1938. ${ }^{15}$

${ }^{9}$ Hamit Bozarslan, "Political Crisis and the Kurdish Issue in Turkey," in The Kurdish Nationals Movement in the 1990s, Its Impact on Turkey and the Middle East, ed. Robert Olson (Kentucky: The University Press of Kentucky,1996), 137.

${ }^{10}$ Henri Barkey, "Under the Gun: Turkish Foreign Policy and the Kurdish Question," in The Kurdish Nationalist Movement in the 1990s: Its Impact on Turkey and the Middle East, ed. Robert Olson (Kentucky: The University Press of Kentucky, 1996), 66.

${ }^{11}$ Taha Baran, 1937-1938 Yilları Arasında Basında Dersim (Istanbul: İletişim, 2014), 26.

${ }^{12}$ Iskân Kanunu, Art. 2 (translation by the author).

${ }^{13}$ Zeynep Türky1lmaz, "Maternal Colonialism and Turkish Woman's Burden in Dersim: Educating the 'Mountain Flowers' of Dersim," Journal of Women's History 28, no. 3 (2016), 165, accessed July 7, 2020, doi: https://doi.org/10.1353/ jowh.2016.0029.

${ }^{14}$ Takrir-i Sükun Kanunu (Law of the Maintenance of Order) of 1925 (Law No. 578, March 4, 1925), (Rep. of Turkey), accessed July 7, 2020, https://www.tbmm.gov.tr/tutanaklar/KANUNLAR KARARLAR/kanuntbmmc003/kanuntbmmc003/ kanuntbmmc00300578.pdf. This law was planned to be valid for two years first, then on March 2, 1927 was extended for two more years, to March 4, 1929. The law conferred extraordinary powers of authority upon the state rulers, including jurisdiction over the death penalty and the pardoning of those convicted. These powers were harshly employed against the Kurdish opposition, including what took place in Dersim (Tunceli) in 1937/8. See Erik J. Zürcher, Turkey: A Modern History (London, New York: I.B. Tauris, 2017), 177.

${ }^{15}$ Serhat Aslan, “Kürdistan'da Doğa / Ekoloji Katliamı,” Toplum ve Kuram: Lêkolîn û Xebatên Kurdî Dergisi 9, (2014), 65, accessed July 7, 2020, https://www.mezopotamyaekoloji.org/wp-content/uploads/2017/03/Kurdistanda Doga Ekoloji Katliami.pdf 


\section{The Genocide in Dersim ${ }^{16}$}

Shortly after Raphael Lemkin coined the term genocide in 1943, ${ }^{17}$ Turkey was among the countries that ratified the Convention on the Prevention and Punishment of the Crime of Genocide (hereafter referred to as "Genocide Convention") on July 31, 1950 as a member state of the United Nations. ${ }^{18}$ Nevertheless, Turkey has never acknowledged or accepted responsibility for the Turkish state's part in such mass crimes, including those taking place before the convention's ratification. On the contrary, Turkey has systematically denied the crimes and continues to do so. In addition to systematically blaming and dehumanizing the victims, the state has mobilized discourses that portray the state itself as the victim in these scenarios.

Despite the existence of strong evidence to support the classification of the militaristic operations in Dersim as genocidal acts, according to the definition set forth in the Genocide Convention, Turkey has denied and minimized these allegations and sought to portray the events of 1938 as a necessary act to civilize the region. ${ }^{19}$ In addition, given the contemporary political climate, few dare to discuss these incidents. As such, neither researchers nor politicians have examined or fully acknowledged the events that took place in Dersim in 1938 as a genocide until recently. ${ }^{20}$ Among these few, Martin van Bruinessen, a Dutch anthropologist who focuses on Kurdish issues, argues that "the brutal Dersim campaign was but the culmination of a series of measures taken in order to forcibly assimilate the Kurds." ${ }^{21}$ He thus offers the term of ethnocide to characterize the operations.

Although Bruinessen rightly shows that the main aim of the state was assimilation rather than extermination, ${ }^{22}$ this does not contradict the classification of the act as a genocide itself, particularly in relation to the case of Kurdish Alevis. Alevi Kurds, in general, and those in Dersim in particular, have remained a great concern for the state's homogenization policies. The Governor of Elaziz, ${ }^{23}$ Cemal Bey, had raised concerns in his report regarding the Kurdishness of Alevis, ${ }^{24}$ while Civil Inspector Hamdi Bey had warned about the rise of Kurdish idealism and identity in Dersim and concluded that civilizing Dersim was a fantasy, in his report referring to Dersim as a boil requiring

${ }^{16}$ In recent years, local authors started to use tertele, a Kurdish term in both dialects (Kurmanci and Kirmancki) for the events in Dersim between 1937-38. However, this term does not meet the meaning of genocide. Tertele refers to depredation, the physical destruction of the property. Old Dersimian used "Qirkirin" (Kurmanci), "Qirkerdan" (Kirmancki) for the events of 1937-38, meaning mass killings/genocide. They would say "Milet qirkirin, malê Dêsim tertele kirin" (Killed people and depredated the property of Dersim). Therefore, the term of tertele is not appropriate to use and also comes with risk, as in the future, it can be used to the refute the mass killing of people in order to deny the genocide.

${ }^{17}$ Raphaël Lemkin, Axis Rule in Occupied Europe: Laws of Occupation, Analysis of Government, Proposals for Redress (Washington DC: Carnegie Endowment for International Peace, 1944).

${ }^{18}$ United Nations (UN), General Assembly Resolution 260, Convention on the Prevention and Punishment of the Crime of Genocide (Genocide Convention), December 9, 1948 (UN Doc. A/Res/260(III)).

${ }^{19}$ Gökçen Başaran İnce, “Zamanında Dersim Nasıl Haber Olmuştu?” December 15, 2011, Birikim, accessed July 30, 2020, https://www.birikimdergisi.com/guncel/577/zamaninda-dersim-nasil-haber-olmustu; Erdoğan Aydın, Ölüm ve Medeniyet Paradoksunda Dersim, Dersim Gazetesi, November 17, 2017, accessed July 31, 2020, http://dersimgazetesi. net/olum-ve-medeniyet-paradoksunda-dersim/; Baran, Yillarn Arasinda Basinda Dersim, 92.

${ }_{20}^{2}$ İsmail Beșikçi, Tunceli Kanunu (1935) ve Dersim Jenosidi (Istanbul: Belge, 1990); Barıș Ünlü, “’Turkishness contract’ and Turkish left," Perspectives: Political analysis and commentary from Turkey, no. 3.13, eds. Ulrike Dufner, Özgür Gürbüz, Semahat Sevim, Yonca Verdioglu (Istanbul: Henrich Böll Stiftung, December 2012), 23, accessed July 31, 2020, https:// www.boell.de/sites/default/files/perspectives turkey 3 eng.pdf; Bilgin Ayata and Serra Hakyemez, "The AKP's engagement with Turkey's past crimes: an analysis of PM Erdoğan's 'Dersim apology'," Dialect Anthropology 37 (2013), 131-143, accessed July 31, https://doi.org/10.1007/s10624-013-9304-3.

${ }^{21}$ Martin van Bruinessen, "Genocide in Kurdistan? The Suppression of the Dersim Rebellion in Turkey (1937-38) and the Chemical War Against the Iraqi Kurds (1988)," in Conceptual and Historical Dimensions of Genocide, ed. George J. Andreopoulos (Pennsylvania: University of Pennsylvania Press, 1994), 149, Academia.edu, accessed June 6, 2019, https://www.academia.edu/2521265/Genocide in Kurdistan The Suppression of the Dersim Rebellion in Turkey 1937-38 and the Chemical War Against the Iraqi Kurds 1988.

${ }^{22}$ Ibid., 9.

${ }^{23}$ Presently Elazığ.

${ }^{24}$ Reşat Hallı, Türkiye Cumhuriyetinde Ayaklanmalar (1924-1938) (Ankara: Genelkurmay Basımevi, 1972), 375. 
excision..$^{25}$ In accordance with those reports, The Şark Plan to promote the assimilation of the Kurds ${ }^{26}$ was formulated by İbrahim Tali Öngören, one of the top architects of the state's homogenization policies. ${ }^{27}$ The Commander of General of Staff Fevzi Çakmak summarize this plan for Dersim as follows: "Dersim should primarily be accepted as a colony, Kurdishness should be melted into Turkishness, and then should be subjected to particular Turkish jurisdiction." 28

Following a seven-year period of preparation for Dersim that began in the 1930s, the implementation of the plan began in 1937. Therefore, the militaristic operations in Dersim during the period of 1937-38 represented an attempt to exterminate the population. Although state documents mainly emphasize the Kurdish character of Dersim, it was not targeted solely because of its ethnic composition but also due to the city's central significance for Kurdish Alevis. ${ }^{29}$ Therefore, the main seyid $^{30}$ families were among those specifically targeted for killing and exile. Seyid Riza, one of the most respected religious and political leaders of Dersim, was one of them.

In addition, the main target of the state was the political structure of Dersim which was based upon two main institutions: the Ocax system and the tribe system. The Ocax system is a religious institution unique to Kurdish Alevi social life, functioning to address major societal issues without the need for any governmental oversight. According to the second article of the Genocide Convention, to classify an event as a genocide does not require a certain number or percentage of a particular group be killed, but, rather, hinges on the calculated intention of the act. Thus, by the definition provided in the second article, the actions of the Turkish state clearly meet the criteria to be classified as genocidal not just because of the intention to kill a number of people but because the intervention was intended to dismantle Kurdish Alevi social structures, ${ }^{31}$ to remove the population from the region, and assimilate those remaining, as clearly stated by Celal Bayar, the Prime Minister, in a speech to Parliament in $1938 .{ }^{32}$

Taking a closer look at Article 2 of the Genocide Convention, genocide is defined as:

[A]ny of the following acts committed with intent to destroy, in whole or in part, a national, ethnical, racial or religious group, as such: (a) Killing members of the group; (b) Causing

\footnotetext{
${ }^{25}$ Ibid.

${ }^{26}$ Baskin Oran, "Ulus Devlet ve Dersim," in 1. Uluslararası Tunceli (Dersim) Sempozyumu Bildiriler, ed. Hıdır Özdemir, et al. (Tunceli: Tunceli Universitesi, 2010), XXVI.

${ }^{27}$ Jandarma Umum Komutanlı̆̆g Raporu (JUK Report) (Istanbul: Kaynak, [1932] 2010), 239. Jandarma Umum Komutanlığ1 hereby (JUK) will be used as the abbreviation.

${ }^{28}$ Original text as follows: “Dersim evvelâ Koloni gibi nazarı itibara alınmalı, Türk camiası içinde Kürtlük eritilmeli, ondan sonra tedricen öz Türk hukukuna mazhar kılınmalıdır," JUK Report, 242.

${ }^{29}$ Recent efforts to argue that the 1937-38 operations in Dersim were not targeting Kurdish identity but only the Alevi community are not accurate. Dersim was targeted because of its position at the intersection of two identities, both equally non grata within a Turkish Islamic ideological state. In addition to the sources referenced in the article, there are quite important witness statements and memoirs containing accounts from soldiers who took part in the operations. One of them writes: "[W]e have started to move on the Kurds in Dersim on July 27, 1938," see, Zeynep Türkyılmaz, "Dersim Soykırımı ve 'Kötülüğün Sıradanlığı,"' Agos, November 11, 2019, accessed March 8, 2020, http://www.agos.com.tr/tr/yazi/23286/dersim-soykirimi-ve-kotulugun-siradanligi. In a documentary film on Dersim 1937-38, Özgür Fındık, “Fındık - 38 Dersim Sürgünleri,” aired on May 4, 2011, YouTube video, 01:06:39, uploaded on December 6, 2018, Can TV, accessed March 8, 2020, https://www.youtube.com/watch?v=ao- qvFXcVg, a Turkish soldier who participated in the operations recalls and says "we came here and gathered, took the Kurds to a stream and killed them," Findik, Kara Vagon, 00:21:07. The same soldier recollects that their commander stated that "there are four traitors in the world. Do you know them? One is the rat, one is the wolf, one is the pig and the other is the Kurd," Findık, Kara Vagon, 00:22:09-00:22:30. A villager in a western city of Turkey that hosted those exiled from Dersim adds that "we were told that Kurds came from the caves, we went to see," Fındık, Kara Vagon, 00:50:19. Despite previous references, recently, state sources have joined scholarly efforts to downplay Dersim's Kurdish character. See Findik, Kara Vagon, 01:06:39.

${ }^{30}$ Members of a sacred lineage/caste who have the rights and duties to perform religious services. Dilşa Deniz, "Kurdish Alevi Belief System, Rêya Heqî/Raa Heqi: Structure, Networking, Ritual, and Functions," in Kurdish Alevis and the Case of Dersim: Historical and Contemporary Insights, ed. Erdal Gezik \& Ahmet Kerim Gültekin (Lexington, London, 2019), 53.

${ }^{31}$ The political structure (ashirets) and the religion structure (the seyids) were attacked first. Leaders were executed and the societal survival mechanisms were ruined.

${ }^{32}$ Suat Akgül, Yakın Tarihimizde Dersim İsyanları ve Gerçekler (Istanbul: Boğaziçi, 1992), 155.
} 
serious bodily or mental harm to members of the group; (c) Deliberately inflicting on the group conditions of life calculated to bring about its physical destruction in whole or in part;

(d) Imposing measures intended to prevent births within the group; (e) Forcibly transferring children of the group to another group. ${ }^{33}$

With the exception of part $(\mathrm{d})$ - which cannot be assessed due to lack of information - all other acts referenced within the article took place. Thus, in contrast to van Bruinessan's argument calling the event 'ethnocide' due to the assimilation policy of the State targeting the Kurds, it is evident that not just Kurdish identity but most importantly Kurdish Alevi identity and the population were targeted. Nearly all state reports about Dersim from that time expressed the opinion that the seyids represented a danger and exerted a negative effect on the society. ${ }^{34}$ Seyids are the members of an important institution of Kurdish Alevism. Accordingly, operations in Dersim were direct attacks on the survival of the Kurdish Alevi community and also sought to eradicate its political and societal structures, which are uniquely shaped by a combination of tribal and religious affiliation. Therefore, given that Dersim operations deliberately targeted the Kurdish Alevi society, which ultimately resulted in the mass killing of between a minimum of twenty percent and fifty percent of the Alevi Kurd population in Dersim, this article argues that the whole process should be considered a genocidal act.

According to theories of genocide, the denial stage is ranked as the last or tenth stage of most genocides. ${ }^{35}$ In Dersim, this stage actually preceded the genocide when the city of Tunceli was formed officially by law 2884 in parliament in 1935 (hereafter Dersim/Tunçeli Law) ${ }^{36}$ one year before the city was physically established, as show below in Figure $1 .{ }^{37}$ Derived from the Turkish words for iron (tunç) and hand (el), respectively, the city's name carried with its connotations of the iron hand or fist (of the Turks). This is strong evidence suggesting the genocide was already being carefully planned prior to 1937-38 and Tunceli was the name given to the region where the planned genocide would take place. Thus, Tunceli and Dersim have always been two dissenting terms and political markers: while Dersim represents the name of the past, evoking Kurdishness, religious belief, and autonomy, Tunceli continues to be reminiscent of the state's intent to Turkify and Islamize, and the culmination of these efforts in the 1938 Dersim genocide.

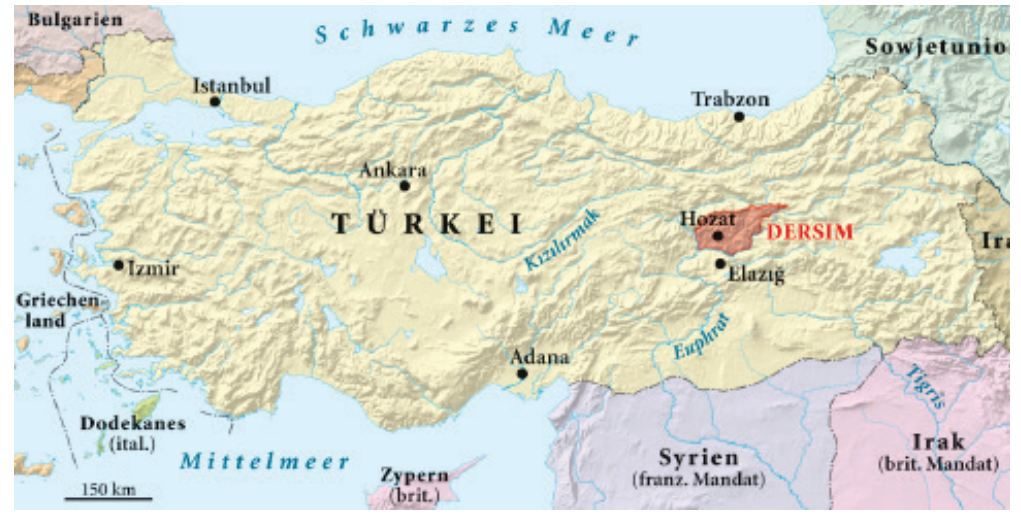

Figure 1. Map of Tunceli/Dersim. Part of the Dersim region was designated as Tunceli city for the military operation of 1937-38.

${ }^{33} \mathrm{UN}$, Genocide Convention, Art. 2.

${ }^{34}$ Ömer Kemal Ağar, Tunceli-Dersim Coğrafyası (Istanbul: Türkiye Basımevi, 1940), 32; Akgül, Yakın Tarihimizde Dersim İsyanları, 162.

${ }^{35}$ Stages of genocide: 1. Classification; 2. Symbolization; 3. Discrimination; 4. Dehumanization; 5. Organization; 6. Polarization; 7. Preparation; 8. Persecution; 9. Extermination; 10. Denial. See Gregory Stanton, "The Ten Stages of Genocide," Genocide Watch, accessed July 6, 2020, https://www.genocidewatch.com/ten-stages-of-genocide.

${ }^{36}$ Tunçeli Vilâyetinin Idaresi Hakkında Kanun (Law on the Administration of the City of Tunçeli) of 1935, (Law No.2884), January 2, 1936, (Rep. of Turkey), Resmi Gazete, accessed July 7, 2020, https://www.resmigazete.gov.tr/arsiv/3195.pdf.

${ }^{37}$ Derived from the Turkish words for iron (tunç) and hand (el), respectively, the city's name carried with its connotations of the iron hand or fist (of the Turks). This is strong evidence suggesting the genocide was already being carefully planned prior to 1937-38 and Tunceli was the name given to the region where the planned genocide would take place. 


\section{Assessing the Harm Inflicted}

Not only did the state plan the genocide, but they also made explicit efforts to suppress knowledge of the death toll and prevent its inclusion in official documents or publications. Considering the Law on the Maintenance of Order (1925) through which the state controlled any actions that might upset the application of their plan before and after Dersim 1937-38, including the media. The British ambassador at the time, Percy Loraine, noted "the Turkish press, ... has preserved a complete silence" ${ }^{\prime 38}$ with exception of "the Son Telegraf, which published on the 14th May an article hinting at trouble in the eastern vilayets. The newspaper was promptly suspended and did not reappear until several days later." ${ }^{39}$ The only voice raised in that period was Necip Fazıl Kısakürek, a conservative religious poet, who was in conflict with the Kemalist cadres. While Kısakürek refused to recognize the Kurdish and Alevi identity of Dersimians, and, like the Kemalist/nationalists faction, referred to the residents as "Muslim," he claimed that the events in Dersim in 1938, "had no similar example in history and at least 50,000 Muslims were killed." 40 Years later on February 19, 1942, the Prime Minister, Ibrahim Refik Saydam, condemned the mass killings due to the use of poisonous gas in a telegram to the Chief of General Staff Fevzi Çakmak. "The gas that [has been] used against its own people has caused mass killings of civilians. As a doctor and a human, I must express that I am very ashamed of it." 41 This telegram clearly shows that a high number of people were killed, although no information is available to indicate exactly how many, as the state kept the records strictly private. As such, there are only two distinct state records, both gleaned from indirect sources, as the state never officially accepted or rejected responsibility for these mass killings.

While scholars and the public lack access to the official records, Serap Yeşiltuna, a Turkish nationalist scholar and politician ${ }^{42}$ is the only one who has been granted access to these documents and she estimated the casualty figure to be $13,801 .{ }^{43}$ In contrast, Necip Fazil Kisakürek suggests this figure likely exceeded 50,000, a figure four times higher than the official records. Since the state continues to prevent access to the archives, ambiguity continues to surround the number of causalities and the number of wounded and forcibly relocated individuals. As such, researchers have mainly used official census data preceding and following the period between 1937-38 to infer the approximate number of causalities. However, in an effort to prevent researchers from using this method, the state sources - most likely deliberately - from 1930 onward, have provided dramatically contrasting estimates, sometimes even provided by the same persons, as discussed below. Since the city itself was newly designed and not yet formally established, official census data remain unavailable. Thus, many individuals counted as part of the population of the towns that came to be considered Tunceli, were later added a second time to the population count to reach the exact number of casualties.

Estimating how many were killed, injured, and exiled is not only challenging due to the state's efforts to suppress the records. Though census data could provide another means of calculating the possible death toll, reports on the regional population vary significantly. The Ministry of Interior indicated that somewhere between sixty-five and seventy thousand individuals were living in Dersim in December 1935. ${ }^{44}$ In contrast, in the book published by Gendarmerie General Command in 1932, this figure was given to be 150,000 by the same minister. ${ }^{45}$ This book was prepared by

\footnotetext{
${ }^{38}$ Şimşir, Ingiliz Belgeleri, 303.

${ }^{39}$ Ibid.

${ }^{40}$ Hasan Demir, Dersim'den Tunceli'ye 38 Katliamı Tanıklikları (Istanbul: Belge, 2011), 55.

41 “Başbakan: Tunceli'de kendi halkına karşı kullanılan zehirli gaz düşmana bile uygulanamaz, utanç duyuyorum!,” T24, November 19, 2014, accessed September 7, 2019, https://t24.com.tr/haber/basbakan-tuncelide-kendi-halkina-karsikullanilan-zehirli-gaz-dusmana-bile-uygulanamaz-utanc-duyuyorum,277596.

${ }^{42}$ She was an independent candidate for Parliament in the 2011 election in her birthplace, Balıkkesir. Though independent, she was actually supported by the Ulusal Party, one of the smallest ultra-nationalist party. She used very anti-Kurdish slogans and gave hate speeches against Kurds. For instance, her billboard slogan was "Rescue Balıkkesir from the Kurds." Another said, "[w] ho should fear, Turks or the Kurds?" See Beyazgazete, "12 Eylül'ün acılar1 yetmedi mi? Irkçı afişten sonra darbe çağrısı," Beyazgazete, February 2, 2012, accessed April 8, 2020, http://beyazgazete.com/ haber/2012/2/2/12-eylul-un-acilari-yetmedi-mi-irkci-afisten-sonra-darbe-cagrisi-1038130.html.

${ }^{43}$ Serap Yeşiltuna, Devletin Dersim Arşivi (Istanbul: Ileri Yayınları, 2012), 29.

${ }^{44}$ İsmail Beşikçi, Tunceli Kanunu,10.

${ }^{45}$ JUK Report, 251; Yeşiltuna, Devletin Dersim Arşivi, 1115.
} 
Kazim Orbay, a high-ranking army officer who was later commanding the operations in Dersim ${ }^{46}$ and only a hundred copies were distributed to particular state officials who would later play a key role in military operations in Dersim. This figure should therefore be considered the most accurate source. The same number was also cited by Naşit Uluğ, a Turkish journalist (and intelligence agent), ${ }^{47}$ one of only a few outsiders who had the opportunity to travel to Kurdistan during that period.

Nevertheless, Martin van Bruinnesen has relied on estimates that place the population between sixty-five and seventy thousand, a calculation justified by his claim that the historical district of Dersim included parts of much larger neighboring cities such as Sivas, Erzincan, and Elazı $\breve{g}$ provinces. Therefore, contemporary authors cite the "much higher population figure of 150,000, apparently referring to larger Dersim." ${ }^{48}$ Baki Öz, a pro-Turkish writer, also argues that Dersim should not be understood only as the nucleus land around Tunceli, but Dersim's tribes dispersion area should also be included. ${ }^{49}$ As such, van Bruinnesen suggests that casualty estimates exceeding forty thousand are greatly exaggerated.

Although both authors are correct in their attempts to account for all those residing within the large geographical area historically referred to as Dersim, the given population figures do not actually contain all the areas they refer to. On the contrary, these figures are based on the actual population of the eight districts, ${ }^{50}$ which later included Tunceli city. Therefore, van Bruinessan's theory is shown to be inaccurate. The population estimate of 150,000 is actually derived from the districts falling within the region of Tunceli, an area outlined for military operations, which Şükrü Kaya, the Ministry of Interior, clearly describes as "the 150,000 population of districts that contains Dersim." ${ }^{51}$ This is clear evidence that state sources referenced two very different figures when addressing different audiences. Although state officials were provided with the 150,000 figure, the publicly shared estimates remained at 65-70,000, a figure that likely accounts for only half of the actual population, leading to the intended confusion among scholars. This also suggests that the number of people to be killed had been planned and calculated prior to the event.

Nuri Dersimi, a Kurdish politician from that period, indicates that the Turkish state surveyed Dersim's population in 1927 and estimated the population to number approximately 270,000, excluding residents of the city of Pülümür. He also criticized Erzincan's Governor, Ali Kemali, for exaggerating the size of the Turkish population in Erzincan while underrepresenting the Kurdish one. ${ }^{52}$ Ömer Kemal Ağar, an important state official of the region in that period, cited the population of Dersim (excluding Pülümür) as 93,117 in 1935 and 105,911 in 1936, a figure that must also be recognized as a misrepresentation due to the large segment of the population that sought to remain unregistered to avoid compulsory military service and taxation. ${ }^{53}$ To support Dersimi's claim, Ulug offers the following example: "Kureyşan's population reaches 2000. If you ask them, this number does not exceed 700. You cannot learn the exact population of any of these tribes; they are afraid that the tax would be raised, thus we cannot hide from the government." ${ }^{54}$ A similar opinion has been expressed by Munzur Çem, a contemporary Dersimian writer, who argues that "Kurds are the people who tend to keep their relation with the state to a minimum - as it is seen as a foreign power- and to avoid paying tax or performing military service." 55

Ibrahim Tali described Dersim as "very crowded and armed. To disarm Dersim is not a matter of days, weeks or months. It is a two-year job." ${ }^{56}$ Such a claim clearly demonstrates the length of

\footnotetext{
${ }^{46}$ Akgül, Yakın Tarihimizde Dersim İsyanları, 157-158.

${ }^{47}$ Beşikçi, Tunceli Kanunu, 145.

${ }^{48}$ Bruinessen, Genocide in Kurdistan, 4.

${ }^{49}$ Baki Öz, Dersim Olayı (Istanbul: Can, 2004), 8.

${ }^{50}$ The eight districts are as follows Pertek, Çemişgezek, Çarsancak (Pêr/Akpazar), Hozat, Ovacık, Pülümür, Nazimiye.

${ }^{51}$ JUK Report, 251.

${ }^{52}$ Dersimi, Kürdistan Tarihinde Dersim, 57-58.

${ }^{53}$ A ğar, Tunceli-Dersim Coğrafyası, 19.

${ }^{54}$ Naşit Hakkı Uluğ, Derebeyi ve Dersim (Istanbul: Kaynak, 2009), 64.

${ }^{55}$ Munzur Çem, Dersim Merkezli Kürt Aleviliği (Istanbul: Vate, 2010), 392-393.

${ }^{56}$ JUK Report, 232.
} 
time that was necessary for the state to prepare for the operations of 1938 and also accounts for the exact two-year length of time for the operations in Dersim. Both Ağar and Ulug rely upon the state's population estimates, that exceeded one hundred thousand. The same approach has been adopted by contemporary ultra-nationalist Turkish sources, who estimate the population of Dersim in 1935 to be $107,723,{ }^{57}$ to quell recent discussions surrounding the suppressing of census data to mask casualty numbers in that period. Thus, to derive casualty estimates using the few available sources, one must consider: a state record dated November 11, 1939 indicating that 13,801 persons had been killed and Kisakürek's figure of 50,000. ${ }^{58}$ Raffi Bedrosyan, an Armenian writer, noted death tolls as "rang[ing] from 13,000 according to Turkish sources-40,000 to U.S. and 80,000 to Kurdish sources." ${ }^{59}$ Despite the lack of the reference, this is the first time the US mentioned a figure.

These are the only figures available. The nationalist scholar Yeşiltuna argues that even the figure of 13,801 is high and does not fit the order of the documentation of 155 folders, a series of reports documenting the years between 1935 and 1938, beginning from August 13, 1935 and ending on September 12, 1939. She argues that the casualty figures should be accepted as 2,0003,000 at most $^{60}$ suggesting that the currently accepted figure is nearly three to four times higher than the actual figures and argues for the replacement of the documents. ${ }^{61}$ However, she fails to explain why and how the documents on Dersim 1937-38 in the folder were replaced in the General Chief Staff's archive, the most secure building in Turkey. If there was a switch, as she suggests, then it must have taken place with the complicity of state officials. In that case, it is the state that changed the figures, meaning they either reduced or increased the numbers. If, on the one hand, the figure was reduced, that means the actual number is higher by more than two or three times. On the other, if the state increased the numbers, it implies that they did not correctly document the actual number of casualties in 1938 and thus gradually increased this figure as they became aware of more accurate estimates. In both cases, it is clear that the state, alone, has the power to alter the figures and any change taking place has the necessity to be in congruence with the interests of the state. The second of the two scenarios is the more probable. As discussed below, the death reports were completed mostly after the 1940s, between five and ten years after the events of 1938, and thus it is important to compare these numbers with the yearly census to determine the most accurate casualty figures.

$\begin{array}{ll}\text { Year } & \text { Population } \\ 1940 & 94,639 \\ 1945 & 90,446 \\ 1950 & 105,759 \\ 1955 & 121,743 \text { (Frrat Development Agency 2013). }{ }^{62}\end{array}$

As evident above, the rate of population growth between 1940 and 1945 reveals a negative trend with the overall population decreasing by 4,193. Between 1945 and 1950, the population increased by 15,313 (seventeen percent) - a figure which represents the most dramatic increasewhile during the period between 1950 and 1955 an increase of 15,984 (fifteen percent took place).

\footnotetext{
${ }^{57}$ Yeşiltuna, Devletin Dersim Arşivi, 13.

${ }^{58}$ Demir, Dersim'den Tunceli'ye, 55.

${ }^{59}$ Raffi Bedrosyan, "Dersim: A First Step in Facing the Past in Turkey," The Armenian Weekly, December 1, 2011, accessed April 4, 2020, https://armenianweekly.com/2011/12/01/dersim-a-first-step-in-facing-the-past-in-turkey/.

${ }^{60}$ In a documentary about the events in Dersim in 1938, Haydar Y1ldirım, a Turkish soldier in that period indicates that the army had tied 500-600 people to each other, fired upon them with machine guns, and threw their bodies into the river. See Findık, Kara Vagon, 00:25:54-00:26:08.

${ }^{61}$ Yeşiltuna, Devletin Dersim Arşivi, 28-29.

${ }^{62}$ Firat Development Agency, Tunceli, December 31, 2003, accessed June 13, 2019, http://investintunceli.gov.tr/tr/files/ rakamlarla-tunceli.pdf.
} 
Şükrü Aslan, who interestingly refers to the 1935 census as the last census before the great exile, ${ }^{63}$ a term by which he avoids any reference to the violence and mass killings that took place ${ }^{64}$ explains this increase in the 1950 census as partially emanating from the return of those exiled. ${ }^{65}$ If we take the average of the two to be $16 \%$ growth, that means the population in 1945 (94,639 plus 15,144 (\%16)) should be 109,781, revealing the unexpected absence of 19,335 individuals. If we combine the estimate of 13,810 causalities with the figure of 19,335, the total number of individuals missing from Dersim during this period is roughly 33,145. Moreover, if we include the missing population between 1935 and 1940 using the same methods of calculation as employed above, 107,723 minus 94,639 is 13,084 . Thus, combining these figures, $(33,145$ plus 13,084 , which represents the normal growth of the population) suggests that 46,229 people were killed at minimum.

In another calculation, if one considers the population of 150,000 in contrast with the 1945 figure, it appears that 59,554 individuals are missing (150,000 - 90,446; 59,554 - 11,818- the forcibly moved population - equals 47,736 ). If we were to add at least 15,000 to account for normal population growth, the figure of the missing population would reach 62,736 . Thus, it is clear that according to two different calculations based on the state sources regarding the census in 1937-38 in Dersim, minimum between 46,000-63,000 people were killed and over one and a half thousand people, mostly children, are missing.

Even the figures calculated above, since they are based on the registered population, do not account for all children. Young children in that period were not usually registered in the census and therefore were not included in figures employed in both calculations. As Dersimians mostly sought to avoid encounters with the state, the registration of young children in particular was irregular and infrequent. Since the penetration of the state was not total, the state mainly put pressure on $m u$ htars ${ }^{66}$ to register the population. Muhtars registered people on an irregular basis to balance the competing demands of the state and the community. Ağar and Uluğ both argue that "a large number of the population is not registered," 67 a fact supported by the document below. The document belongs to the family of Bertal Axa, as shown in Figure 2, who was a merchant. The document was provided at the behest of his grandson, upon the condition that it be used only for cadastral and inheritance purposes. Subsequently, such documents were rarely furnished given their potential to be used as evidence of crimes. ${ }^{68}$

${ }^{63}$ I have italicized the term the great exile for emphasis. In the original, Şükrü Aslan refers to "Büyük sürgün" (the great exile). See Şükrü Aslan, "Genel Nüfus Sayımı Verilerine Göre Dersim'de Kayıp Nüfus,” in Herkesin Bildiği Sır: Dersim, ed. Şükrü Aslan (Istanbul: Iletişim, 2010), 404.

${ }^{64}$ Several sentences later, he cites a figure which estimates the death toll to be 13,100.

${ }^{65}$ Aslan, Genel Nüfus Sayımı Verilerine, 404.

${ }^{66}$ These elected village and neighborhood representatives act on behalf of state officials. See International Foundation for Electoral Systems, Elections in Turkey: 2019 Local Elections: Frequently Asked Questions (Washington DC: Middle East and North Africa: International Foundation for Electoral Systems, March 25, 2019), 1, accessed July 31, 2020, https://www. ifes.org/sites/default/files/2019 ifes turkey local elections faqs final.pdf

${ }^{67}$ Uluğ, Derebeyi ve Dersim, 64; Ağar, Tunceli-Dersim Coğrafyası, 18.

${ }^{68}$ Baskin Oran, “1938 Dersim: Bir belge de Nazimiye Nüfus Müdürlüğ̈̈’nden!,” Radikal, August 28, 2014, accessed July 29, 2019, http://www.radikal.com.tr/yazarlar/baskin-oran/1938-dersim-bir-belge-de-nazimiye-nufusmudurlugunden-1209663/. 


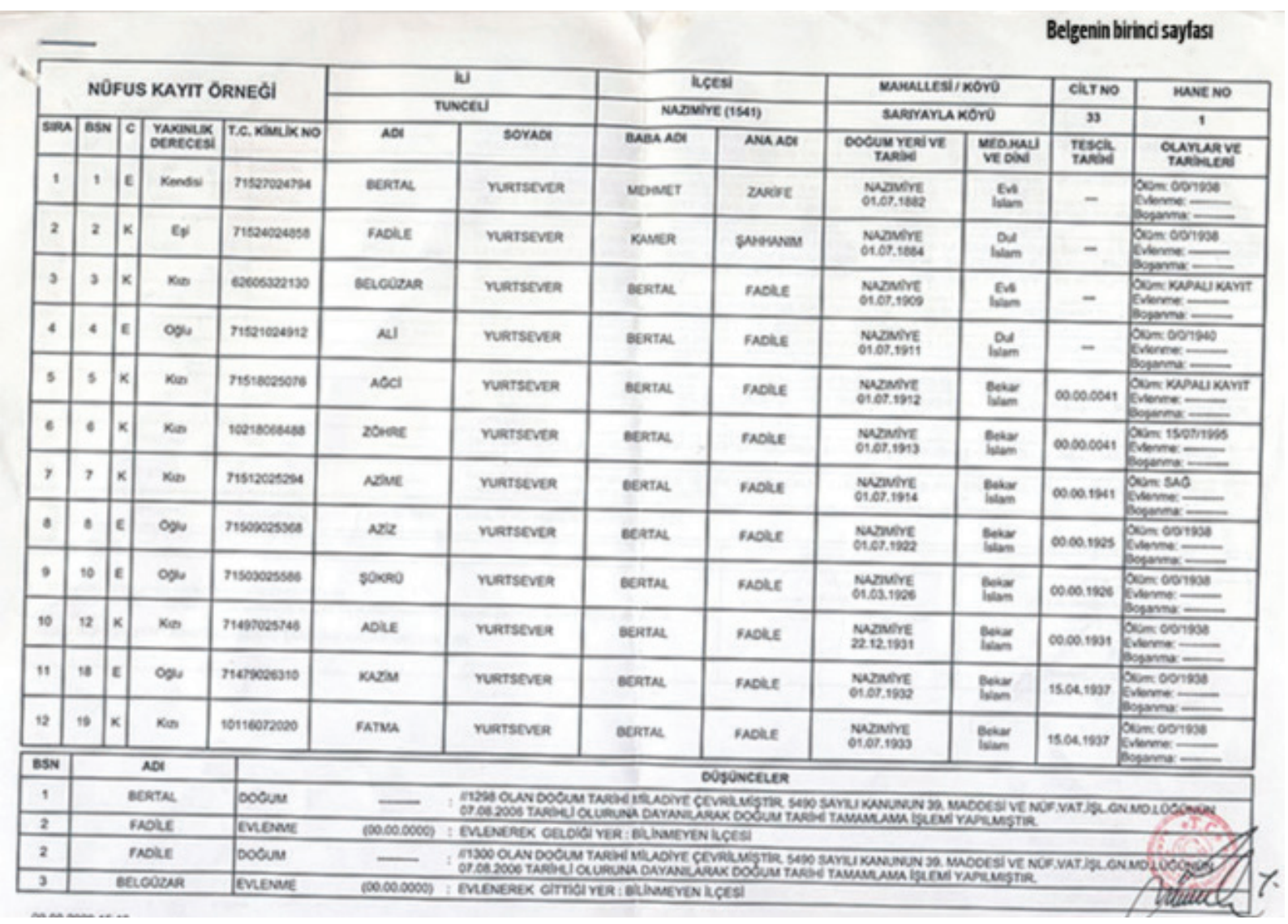

Figure 2. Document belonging to family of Bertal Axa. See Radikal, 29/08/2014. ${ }^{69}$

Based on the above document, Ağci (1912), Zöhre (1913), and Azime (1914) ${ }^{70}$ were registered on the same date of 1941, while the first four people have not been registered at all, indicating that approximately seven people out of twelve may not have been registered before $1936,{ }^{71}$ which would amount to nearly half the population. This, in turn, supports the previous estimates of the unregistered population and the state's estimate that 150,000 individuals resided in Dersim before the genocide. The fact that so many people were registered after 1941, three years after the genocide, explains why it was not possible to count the causalities from bombings, poisonous gas, burning of forests, stabbing, and the use of machine guns in indiscriminate mass killing at that time. It is clear from the document that, particularly in 1938, no exact count of the causalities had been attempted. The state then began its efforts to determine the approximate death toll, as potential victims would have been registered a few years later. According to the document above, only three out of twelve people were registered in the 1935 census. Therefore, neither the population figures below a 100 thousand are correct, nor the given casualty figure of 13,810. In another report, the Third Army Inspectorate indicated that "in two searches and a total of seventeen days, 7,954 persons have been taken out of the searched region, dead or alive." ${ }^{\prime 2}$ If we compare these seventeen days with the larger two-year timeframe, it is not hard to imagine that the true number of casualties must have

${ }^{69}$ Ibid.

${ }^{70}$ The correct Kurdish spelling is Axcê, Zöra, and Ezime.

${ }^{71}$ In the news given about the document, it was indicated this document was only provided for purposes of cadastre and family hereditary transmission. Later, when the state realized that it could reveal the number of causalities, it was not permitted to be given to individuals. This is further evidence for the exact number of causalities. See Oran, 1938 Dersim.

${ }^{72}$ Kaynak, Genelkurmay Belgeleri II, 203, 205. 
been significantly higher. Because of the massive number of causalities, the state, perhaps either reluctant or unable to provide the exact number of causalities, has chosen to employ a definition that relies upon the distinction of dead or alive.

Regarding the 11,818 people forcibly removed, which was a figure common to all reports, ${ }^{73}$ particularly that by Öngören, it is clear that the state had initially planned the removal of 2,000 people, then went on to add an additional $5,000,{ }^{74}$ and subsequently, once again doubled this figure, further evidence that mass extermination was the state's ultimate intention. These figures could indeed be at least partially accurate, as the process of removal had to be more carefully planned and carried out. ${ }^{75}$ Nevertheless, this figure cannot represent the entirety of affected persons because it does not account for the thousands of young children who were removed from their families ${ }^{76}$ and forcibly adopted by Turkish military officials for Turkification and Islamization. In the document above, two children were killed in 1938, while two were declared as a closed record, meaning they are lost persons. Since both of them were young women, this effectively means that they were either abducted and likely engaged in compulsory sex work, committing suicide to avoid this end, ${ }^{77}$ or were killed but were not found. Thus, excluding Ali and Zöhre, ten members of a family of twelve ${ }^{78}$ were killed or lost in the years 1937 or 1938. If we carefully study these records, we note that there were five children under the age of sixteen, and five adults between twenty-four and twenty-nine, so there were only two males that could have potentially been involved in the fighting from that family: the father and Ali. As we know, the father was a merchant and his son worked with him, indicating that none of these family members could be considered a "rebel" in any sense of the word, and so were unlikely to be targeted for removal. Moreover, the father Bertal was actually a tradesman and collaborating with the state by providing feed for their horses. ${ }^{79}$ As such, this document clearly reveals that this family was likely subject to a planned but indiscriminate killing of whomever the state could access and target effectively. As indicated above, newborn babies and the unborn population (not knowing how many women were pregnant) have also not been added to the figures. There are many eyewitness testimonies recalling the killing of pregnant women with bayonets by the soldiers and their unborn children as well as the killing of young infants. ${ }^{80}$

According to a careful study of the Dersim/Tunçeli Law (1935), article 34 allows for any person associated with the "crimes" committed by any other individual either from Dersim who has traveled to the provinces of Elazığ, Malatya, Sivas, Erzincan, Erzurum, Gümüşhane, Bingöl, or persons from there who committed such related crimes in Dersim, to be included under the jurisdiction of the special courts located in Tunceli. ${ }^{81}$ This provision made it possible for the state to target specific, particular individuals even those residing outside of Tunceli's borders. Furthermore, these cities used to be largely populated by Kurdish Alevis, suggesting that-although the operation was portrayed as applying chiefly to the area renamed Tunceli-in fact, the jurisdiction of Tunceli Law and associated operations included nearly the whole Kurdish-Alevi region. This suggest that figures accounting only for the Tunceli population would not include the population killed in these additional cities nor the Dersimians killed in other parts of Turkey. For instance, a majority of the young males taken for military service in that period never returned. ${ }^{82}$ To date there has been no research on this matter.

\footnotetext{
${ }^{73}$ JUK Report, 13-17.

${ }^{74}$ Hüseyin Aygün, Dersim 38 Resmiyet ve Hakikat (Ankara: Dipnot, 2010), 99.

${ }^{75}$ Yeşiltuna, Devletin Dersim Arşivi, 300-301.

${ }^{76}$ Rose Polat Agum, Bego-Dersim 1938 ve Sonrası (Istanbul: Belge, 2018), 70.

77 Ibid, 59.

${ }^{78}$ Oran, 1938 Dersim. Actually, fifty-four members of the family were killed and the grandmother committed suicide when she heard that the family had been massacred, making a total of fifty-five lives lost. The document is based on the account of only one of the nucleus family members from within the broader family. See Oran, 1938 Dersim.

${ }^{79}$ Munzur Çem, Qurzeli Usiv'in 70 Yalı (Istanbul: İletişim, 2014), 68-69.

${ }^{80}$ Demir, Dersim'den Tunceli'ye 38, 179.

${ }^{81}$ Beşikçi, Tunceli Kanunu, 18.

${ }^{82}$ Agum, Bego, 85.
} 
Apart from the killed or forcibly removed populations, the remaining residents must also be considered a population deeply and negatively affected by the events of 1938, a matter which is included in the definition of genocide. Thus, the studies focused only on the final death toll, a partial acknowledgement of the true impact of a genocide or mass killing. In the case of Dersim, all the leaders and the nearly half of the population of the community were killed and/or forcibly displaced from their community. In her memoir, Ane Xatun, the surviving granddaughter of a former member of parliament Diyap Axa, describes how she suffered from insomnia as she tried to answer researchers' questions about the events of $1938 .{ }^{83}$

There is additional evidence that more killings were planned following the initial operations. A message from the Ministry of Interior to the Prime Ministry office dated May 18, 1937 indicates that, "instead of settling our troops in the heartland of Dersim to struggle until they give up, it was better to undermine their living conditions by destroying villages, herds and crops." ${ }^{84}$ As such, to increase the ultimate number of long-term causalities, they sought to destroy the material bases of the population's survival and livelihood such as livestock by burning crops, ${ }^{85}$ bombing the natural environment, and looting and burning houses, leaving many survivors to suffer from hunger, malnutrition, and at risk of infectious disease. Moreover, state operators were also actively engaged in the deliberate killing of the wounded..$^{86}$ The lack of medical care and accommodation during the exceptionally long and harsh winter conditions that characterized mountain life caused more suffering and indirect causalities ${ }^{87}$ than are able to be accounted for in the overall death figures.

There are various testimonies addressing the trauma of genocide ${ }^{88}$ and its effects on mental health including suicidal tendencies, crying to the point of blindness and eye damage, complete silence, as well as psychosomatic consequences that appear in various oral history studies, deep interviews, ${ }^{89}$ and more recently published literature on the Dersim genocide and forced displacement. ${ }^{90}$ All of this speaks clearly to the heavy trauma inflicted upon Dersimian society. ${ }^{91}$ Moreover, the problems resulting from widespread sexual violence against women ${ }^{92}$ and potential pregnancies, suicides, and the killing of babies ${ }^{93}$ is not accounted for and there is total silence from both Dersimians and the Turkish state on the matter. While the state has kept silent to hide its crimes, larger society also remains silent because of the shame and trauma surrounding sexual crimes.

\section{Prior to the Nazis, Gas was Used for Mass Killing in Dersim}

The first documented use of poisonous gas in Dersim is described by Nuri Dersimi, where "the region was covered by a thick veil of mist due to the poisonous gas bombs from planes, where no living creature was left, and the scene was of houses and the forests set on fire, which looked like a state of hell." ${ }^{\prime 94}$ Because of his books, in which he gives very important and detailed information

\footnotetext{
${ }^{83}$ Fatma Betül Günday, “Adın Perihan Olsun” Diyap Ağa'nın Torunu Ane Hatun'un Hikayesi (Istanbul: İletişim, 2016$), 152$.

${ }^{84}$ Yeşiltuna, Devletin Dersim Arşivi, 511.

${ }^{85}$ Demir, Dersim'den Tunceli'ye, 192; Agum, Bego, 32.

${ }^{86}$ Akyürekli, Dersim Kürt Tedibi 1937-1938, 187.

${ }^{87}$ Agum, Bego, 68.

${ }^{88}$ Aygün, Dersim 38, 100; Günday, Adın Perihan Olsun; Agum, Bego, 72.

${ }^{89}$ Ṫhami Algör, Ma Sekerdo Kardaş? "Dersim 38" Tanıklıkları (Istanbul: Doğan Kitap, 2010); Cemal Taş, Dağların Kayıp Anahtarı-Dersim 1938 Anlatıları (Istanbul: İletişim, 2011); Fındık, Kara Vagon, Dersim- Kırım ve Sürgün, 43-219; Celal Yıldız, Dersim Dile Geldi-Dersim Otuz Sekiz'in Çocukları Konuştu (Ankara: Nika, 2012); Gündoğan and Gündoğan, Dersim'in Kayıp Kızları, 2016.

${ }^{90}$ Emirali Yağan, Dersim Defterleri - Beyaz Dă̆'da Bir Gün (Istanbul: İletişim, 2013); Hasan Sağlam, Yasak Mıntıkanın Çocukları (Istanbul: Totem, 2015); Hasan Sağlam, Topră̆ına Tutunanlar-Yasak Mıntıkanın Çocukları II (Istanbul: Totem, 2018); Günday, Adın Perihan olsun, 2016; Agum, Bego.

${ }^{91}$ Mustafa Erdoğan, "Dersim 38," interview by Dilşa Deniz and Hasan Kaplan (September 2009), in Mazgirt, Dersim, unpublished audio-visual recording.

${ }^{92}$ Agum, Bego, 60.

${ }_{93}^{93}$ Agum, Bego, 42, 43, 58.

${ }^{94}$ Dersimi, Kürdistan Tarihinde Dersim, 291.
} 
in relation to Dersim and other Kurdish massacres, Dersimi himself has been targeted in an effort to discredit him. As such, for nearly seventy years, the role of poisonous gas in mass killings was not taken into consideration seriously until it was officially referenced by a former Ministry of Foreign Affairs and then Police Chief, Ihsan Sabri Çağlayangil, in 1986. In an interview, Ihsan Sabri Çağlayangil stated that "through the entrance of the caves they poisoned them like rats." ${ }^{95}$ In a news report by Tan Gazette dated August 3, 1937, it is indicated that there was a training course in Elazı ğ for that same purpose. ${ }^{96}$ Thus, rumors still circulate that this gas was actually tested in Dersim ${ }^{97}$ prior to its use in Nazi Germany. ${ }^{98}$ Furthermore, in a telegram from the general inspectorate and commander of the operation in Dersim, Abdullah Alpdoğan, to Ankara a request for supplies of gas was formally made, as shown below in Figure 3.

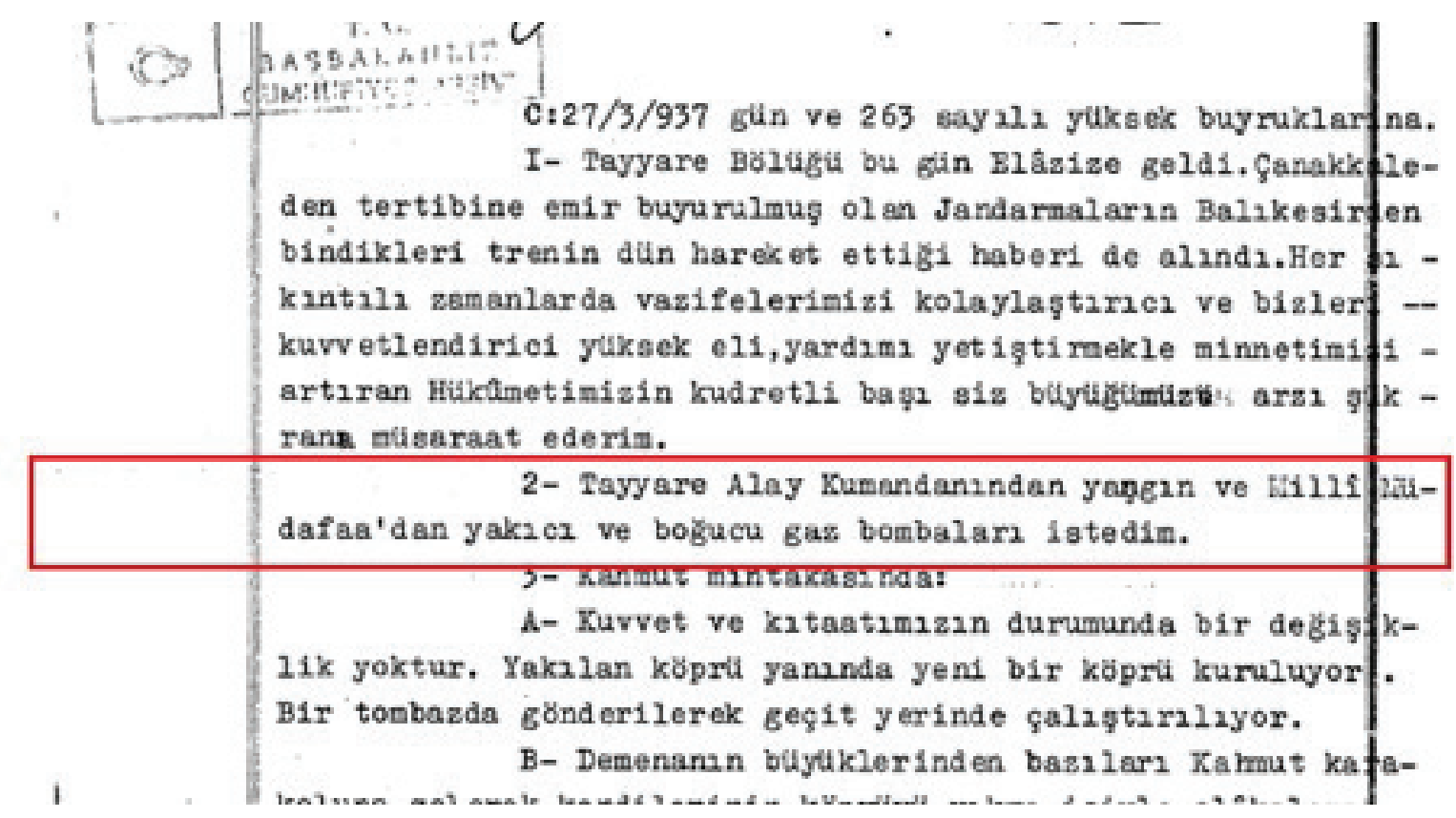

Figure 3. Request for gas supplies. Source: Dersim Gazetesi9 ${ }^{99}$

In the communication, twenty tons of "Chloracetophenon, Iperit and so on" were ordered, and the request was signed by Mustafa Kemal Atatürk on August 7, 1937. ${ }^{100}$ This request makes it clear that a formal plan was made in 1937 after the initial series of operations in Dersim, and was implemented in 1938, which resulted in the planned mass killings. Another document from the Second Directorate Undersecretaries of Air Force to the Prime Ministry office, dated October 20, 1937, indicates that the final parts required for the construction of the latest air force fleet had arrived from the United States and the necessary annual equipment-worth $\$ 200,000$ - would be

\footnotetext{
95 “Çağlayangil: Ordu Dersim Kürtlerini kesti, fare gibi zehirledi!” T24, November 19, 2011, accessed July 9, 2020, https:// t24.com.tr/haber/caglayangil-ordu-dersim-kurtlerini-kesti-fare-gibi-zehirledi,182465.

${ }^{96}$ Murat Aydın, "Dersim" de kimyasal izi ortaya çıtı," CNNTürk, December 4, 2013, accessed June 8, 2019, https://www. cnnturk.com/guncel/dersimde-kimyasal-izi-ortaya-cikti.

${ }^{97}$ Nesimi Aday, "Karga Bülbül Olmaz," Dersim Gazetesi, June 27, 2017, accessed April 4, 2020, http://nesimiaday.com/ index.php/2017/06/27/karga-bulbul-olmaz/.

${ }^{98}$ For a detailed discussion, see Gürdal Aksoy, "Gas at 'Home,' Gas in the World, On the Use of Poison Gas by the Turkish State in Dersim," Academia.edu, March 7, 2020, accessed March 18, 2020, https://www.academia.edu/42159488/Yurtta Gaz Cihanda Gaz Tc Devletinin Dersimde Zehirli Gaz Kullanmas\%C4\%B1 \%C3\%9Czerine Gas at Home Gas in the World On the Use of Poison Gas by the Turkish State in Dersim.

${ }_{99}$ Pirha, Dersim Katliami; Dersim Gazetesi, Zehirli Gazlar Almanya'dan.

${ }^{100}$ Ibid.
} 
purchased by the Turkish Embassy in Washington, DC. ${ }^{101}$ All these preparations were made in the same year in which the Prime Minister İnönü had stated that the government already exercised full control over Dersim, as evident in the headlines of Son Haber on June 15 and Haber on June 18, 1937. ${ }^{102}$

\section{Denial Process, Methods and Results}

The hyperbolic rhetoric of a threatened uprising in an uncontrolled area was used to rally popular support for the destruction of Kurdish Alevis in Dersim. Until recent years, documents providing evidence of the use of poisonous gas received little public attention. In addition, many Dersimians were successfully convinced that neither M. Kemal, nor Ismet Inönü, had been involved in these events. Diyap Axa, one of the six first Dersim Members of Parliament (MP) in the first parliament (1920-1923), was invited by Mustafa Kemal to be representative of Dersim. Six years after his death, his family was massacred in 1938 too. His grandaughter Ane Xatun was the only family member who survived. Ane Xatun, in her memoir, expresses her strong opinion-common among Dersimians - that the Chief Commander of General Staff, Fevzi Çakmak, who was particularly hostile to the Kurds and Alevis, ultimately acted to rescue the surviving population in their final hour. Without mentioning his name, Ane Xatun recalls her meeting with a minister in which she expressed her support of a person connected to Fevzi Çakmak's family for election. This surprised the minister greatly, leading him to inquire about the underlying reason. In response, she noted that, "we owe him if a few of us have survived." He subsequently asked: "Do they really know that it happened just like this?" When she responded affirmatively, the minister recounts the following story:

I am a minister now but I was a lieutenant in '38 and was responsible for the telexes. It was not Fevzi Çakmak, it was Iran's Shah who rescued you... When the army was transferred to Elaziğ Uluova, they prohibited any press members' entrance. An Iranian journalist reports to Iran that he has heard that Alevis have been massacred in Dersim. In that evening at 6 $\mathrm{pm}$ there was a note from Iran in which they asked for a stop to the massacre of Alevis. This note was discussed among the General Staff personnel for a while but later nobody paid any attention. The second note arrived at $4 \mathrm{am}$ in the morning in which Iran said they were going to call back all their embassies and stop all relations with Turkey due to the massacre of Alevis in Dersim. ${ }^{103}$ In that period Turkey was heavily dependent on Iran's petrol, gas, even sugar and tea-all were imported from Iran. Fevzi Çakmak was in the General Staff office in Ankara that time, and after that second note he flew to Elazığ and stopped the massacre. ${ }^{104}$

These remarks illustrate that the perpetrators were personalities such as Mustafa Kemal Atatürk, İsmet İnönü, and Fevzi Çakmak ${ }^{105}$ despite widespread opinion to the contrary. These remarks also demonstrate the prevalence of narratives denying the nature of the Dersim events as a planned genocide. More importantly, it suggests that, if not for the intervention by the Shah of Iran, the state would have continued these indiscriminate massacres. Given Çakmak's role, as the planner and commander of the Dersim genocide, his widespread last-minute depiction as the savior is in contrast to the actual, devastating consequences of his actions. Such portrayals make sense in the context provided by Ane Xatun's memoir, although we lack additional supporting sources. Iran's connection must also be considered carefully here given their historical connection to Alevis in the

\footnotetext{
${ }^{101}$ Ibid.

${ }^{102}$ Baran, Basinda Dersim, 206, 213; Dersimi, Kürdistan Tarihinde Dersim, 277.

${ }^{103}$ Due to the Alevi's support of the Prophet Muhammed's son in-law Ali, and thus the Safadi, Alevis have long represented a fault line between the Safadi and Ottoman periods. In particular, after the defeat of Seljuk by the Safadi, Ottomans became suspicious of Alevis and their connection with Safadi. Thus, during the Yavuz period (1512-1520), more than 40,000 Alevis were massacred. Although Safadi were successful in forming the 12 Imam Shia sect of Islam, they became somewhat distanced from the Alevis. However, Iran continued to disseminate propaganda among the [mostly Turkish] Alevis. In contrast, Kurdish Alevis kept their distance.

${ }^{104}$ Günday, Adın Perihan Olsun, 134-135.

${ }^{105}$ I personally heard the story of Fevzi Çakmak's "rescuing" recounted by many people during my childhood, including my father and mother. It struck me as quite strange indeed and it only began to make sense in the larger context provided by Ane Xatun's memoirs.
} 
past, which could have been a resource to attract international attention. The Turkish state must have been aware of this potential and likely intervened to prevent such actions, at least to some degree.

\section{"Fighting Feudalism" as Denial of Genocide: The Leftist Movement and State Policy in Dersim}

Although the air bombardments were mostly focused in areas where some tribes resisted the operations - referred to as the prohibited zone-in the majority of Dersim no resistance to speak of was present. Death squads went into towns, villages, and hamlets to seek out local leaders-both religious and otherwise - as well as individuals whose names appeared in official records, such as in the gendarmery, police, or in court records. ${ }^{106}$ These individuals were rounded up and killed in certain locations used as execution centers. Several testimonies provide eyewitness accounts of this process. These accounts, as well those of survivors, report that machine guns and rifles were used in the executions. Moreover, many were executed with bayonets to save bullets, indicating the enormous number of executions. Machine guns were used to ensure there were no accidental survivals.

While executions continued to take place, the media coverage sought to dehumanize the victims, invoking the ultra-nationalist Turkish ideological approach which has persisted to this day. ${ }^{107}$ The local population/victims were portrayed as bandits and savages who robbed people, refused to pay their taxes and complete military service, and believed in a "primitive" religion and who were, in essence, themselves primitive. ${ }^{108}$ Moreover, they were portrayed as being manipulated by the axas ${ }^{109}$ and seyids who resisted the reforms and civilization ${ }^{110}$ promoted by the Turkish state for their own benefit. This dehumanization process succeeded in disseminating perceptions of Dersim as an area of savagery and banditry, ${ }^{111}$ metaphorically represented as an open sore, a medical problem to be cured or excised. ${ }^{112}$ All of these factors support the classification of the events as a genocide.

All media outlets, including those considered progressive, such as the Tan Gazete, ${ }^{113}$ expressed support for the Kemalist policies against Kurds and Dersim in 1937-38. In various news reports, Tan employed a language of dehumanization to describe Dersim and its inhabitants. For instance, in a news segment by Latif Erenel, Dersimians were referred to as "the people who are slaves and stripped of any rights. They spend their life in darkness, benightedness and fear like something more animal than human."114 Similarly, a Tan headline dated June 24, 1937, read "The Head Plunderer, Brigand Seyid Riza ${ }^{115}$ Pleaded for Mercy."116 Cumhuriyet, which was also considered a progressive daily newspaper, had become one of the most nationalist and thus supportive of ultranationalist ideology in Turkey and of the Dersim genocide. On June 27, 1937, Cumhuriyet's headline read: "Tunceli's scoundrels have been exterminated."117

After 1938, the phrase "Dersim hadisesi (Dersim incident)" was widely used to deny the genocidal nature of the events and downplay the atrocities that took place. While the terms genocide or mass killing simultaneously encompass the ethnic, religious, and political aspect of the killings, the term incident does not suggest such connection or imply the existence of any perpetrators. On

\footnotetext{
${ }^{106}$ Fadime Deniz, Dersim 38, personal communication with author, Istanbul (October 2009).

${ }^{107}$ See the hate speech in Uluğ, Derebeyi ve Dersim, 49; Beyazgazete, 12 Eylül'ün acıları yetmedi.

${ }^{108}$ Baran, Basinda Dersim, 109.

${ }^{109}$ Bulut, Dersim Raporlarl, 269. Axa refers to someone who is a tribal leader. It can also refer to someone who owns large amounts of land. In the Dersim case, axa, refers mostly to the name of the tribal leader.

${ }^{110}$ Baran, Basinda Dersim, 92.

${ }^{111}$ Bulut, Dersim Raporları, 211, 267.

112 JUK Report, 224.

${ }^{113}$ Baran, Basinda Dersim, 113.

${ }^{114}$ Ibid., 125.

${ }^{115}$ The Kurdish leader of Dersim.

${ }^{116}$ Baran, Basinda Dersim, 224.

${ }^{117}$ Ibid., 219.
} 
the contrary, it remains a neutral term and implicitly represents all parties as equals. In the case of Dersim, this term was particularly useful in concealing the state's role as the perpetrator of genocidal acts against Kurdish Alevis. Rather, the dominant narratives sought to represent these acts as a relatively minor event to manage a small faction of rebels. Thus, the term suggests the victims, as instigators, were to blame, while suggesting that the state was compelled to act in favor of societal order, despite the resulting casualties. As such, the contradictions and discrepancies between the credible sources and Turkish archival sources, and Turkish nationalist narratives ${ }^{118}$ need to be taken into account, and thus especially in the case of the Dersim genocide and in the contemporary climate of Turkish academia, where the available sources remain heavily censored.

To buttress the denial process, the term incident always accompanied narratives describing the "uprising" in Dersim, not just in the language used by the state but also by the Turkish leftist movement in the only region where progressive politics dominate. Although there was some resistance to the heavy military operations, there was, in fact, no real uprising. ${ }^{119}$ Nevertheless, the rhetoric of an uprising was widely employed by the media. This idea was employed ironically alongside narratives claiming the tribes of the region were disarmed, ${ }^{120}$ almost all leaders were arrested ${ }^{121}$ and seven of them hanged in 1937, including Seyid Riza and his son. ${ }^{122}$ These narratives also emphasized that the state was in full control of the region, a conviction that is also clearly apparent in Prime Minister İsmet İnönü's speech in Parliament in $1937^{123}$ and also in Prime Minster, Celal Bayar's speech, in 1938, ${ }^{124}$ and still used effectively for mass killings in 1938.

The uprising discourse was also the prominent discourse invoked by the leftist movement following the genocidal process from the 1970s until the 1980 coup, though it has become less prominent today. During the Dersim genocide, the leader of the Turkish Communist Party (TKP), Ismail Bilen, and a political refugee in the Soviet Union, published Yeni bir Kürt Ayaklanması (A New Kurdish Uprising), using the pseudonym Rasim Davaz, in which he clearly defends the military operations in Dersim.

It has been more than two months that the Ankara Government fights against a backward uprising by the Kurdish tribes in Dersim region. The feudal components, despite the reforms by the Kemalist Party, succeeded in surviving in this far-off region of the country. This region was renamed Tunceli last year. Dersim's dominant classes have succeeded in securing their privileges despite the laws in force ${ }^{125}$

Like all the Alevi regions, Dersim suffered from extreme poverty and possessed little land suitable for agriculture, being largely comprised of a rough highland where Alevis took refuge to avoid attacks from the Ottoman and later Turkish state and attempts to forcibly convert Alevis to (Sunni) Islam. Given the limitations inherent to a region with insufficient arable land, inhabitants resorted to some plundering in Dersim as well as in the neighboring towns. ${ }^{126}$ In Halis Paşa's report it is clearly indicated that, in these acts, they avoided killing ${ }^{127}$ and never committed sexual attacks, prohibited as these were by their religion and culture. The raids were thus restricted mostly to food-based plundering to secure livestock, wheat, and other subsistence items and were ultimately driven by the poverty resulting from the Turkish-Islamic pressure on the region.

Despite conditions of acute poverty and starvation, there were no capitalist-style classes, and thus communists were ideally situated to defending a better life for the suppressed population.

\footnotetext{
${ }^{118}$ Benny Morris and Dror Ze'evi, The Thirty-year Genocide: Turkey's Destruction of Its Christian Minorities, 1894-1924 (Massachusetts: Harvard University Press, 2019), 8.

${ }^{119}$ Baran, Basinda Dersim, 213.

${ }^{120}$ In a state document, it is indicated that before the genocide the state had intelligence on approximately 5,000 firearms in Dersim, and thus was forced into obtaining a certain number of arms. See Uluğ, Derebeyi ve Dersim, 56-68; Yeşiltuna, Devletin Dersim Arşivi, 13.

${ }^{121}$ Yeşiltuna, Devletin Dersim Arşivi, 526.

${ }^{122}$ Akyürekli, Dersim Kürt Tedibi 1937-1938, 140.

${ }^{123}$ Baran, Basinda Dersim, 206.

${ }^{124}$ Akgül, Yakın Tarihimizde Dersim İsyanları,155.

${ }^{125}$ Beşikçi, Tunceli Kanunu, 141.

${ }^{126}$ Dilşa Deniz, "Dersim'in Ekonomi Politiği İçinde Talanın Yeri: Antropolojik Bir Yaklaşım,” in Dört Dă̆a Sı̆̆mayan Kent, Dersim Üzerine Ekonomi-Politik Yazılar, ed. Şerif Gürçağ Tuna and Gözde Orhan (Istanbul: Patika, 2013), 87, 90, 103.

${ }^{127}$ JUK Report, 250.
} 
Despite this fact, Ismail Bilen, chair of the TKP, justified the mass killings that involved tens of thousands of people in one defenseless region as necessary for the sake of Turkish modernism. The Turkish leftist movement's Kemalist/nationalist character becomes apparent in this particular example and has been criticized by a relatively small number of leftist intellectuals and organizations. Ismail Beşikçi, a Turkish academic who served seventeen years in prison due to his research on Kurdish issues in Turkey, has criticized the leftist movement "as the partner of Turkish State's colonialist massacres over the Kurdistan," remarking that:

They [leftists] are against the Kurdish nation who have struggled against conquests, and colonialism, those who have struggled for the right to self-determination. The Kurdish national movement was discredited in every sentence of their reports. Accordingly, they designed reports in which they praised it's [Kemalist secular nationalism] acts and evaluated them as 'progressive' and 'revolutionary. ${ }^{.28}$

Both the Kemalist state and various leftist groups suppressed Kurdish political organizations operating in Dersim. In that period, the only Turkish leftist group supportive of the thesis of Kurdistan's status as a colony ${ }^{129}$ and critical of the leftist movement for its Kemalist characteristics was the Kurtuluş ${ }^{130}$ movement. ${ }^{131}$ As such, it gained support and Dersim become its stronghold for a short period of time between the 1970s and 1980s. Interestingly, this group was targeted and nearly all its cadres were assassinated between 1976-1980, including the first and the only assassinated woman, an engineering student from Dersim (Aynur Sertkaya), and the first high school student executed by hanging (Necdet Adal1). ${ }^{132}$ Some of the deaths were suspicious "accidents." Most of the perpetrators were never found and so the deaths remain labeled as unknown killings, like hundreds of other political killings inculpating the deep state. Gradually, Kurtuluş's members were eradicated from the city, alongside other Kurdish political organizations such as Kawa and Tekoşin. ${ }^{133}$ Another Kurdish leftist organization, the Kurdistan Workers' Party (PKK), was blamed for being ilkel milliyetçi (primitive nationalist) and thus heavily attacked by some of these leftist organizations as well as the state. While the organizations sensitive to the Kurdish and Alevi identity have left Dersim, even those who had engaged in Kurdish politics on a legal basis were hunted by the state. Other groups resistant to these identities have for the most part been left to freely engage in their activities. It should be further noted that the most effective persons among the leftist organizations in favor of Kurdish identity or themselves in Kurdish national were all brutally killed by the state, such as Huseyin Cevahir (in Istanbul 1971), Ibrahim Kaypakkaya (in Diyarbakır 1973), and also an Armenian, Orhan Bakır (Armenak Bakırciyan, in Karakoçan/Elaziğ1980).

In Dersim, the great majority of the political ideology was shared between the most leftist organizations' policies and the state's official TIS ideology. The Kemalist tone within the leftist movement provides additional evidence of the state's homogenization policies and its efforts to influence and manipulate the leftist movement as well as its associated discourses. As Beşikci points out, "the success of the Kemalists' is to make itself be defended by the socialists," 134 while Ahmet

\footnotetext{
${ }^{128}$ Beşikçi, Tunceli Kanunu, 145.

${ }^{129}$ Ünlü, Kürdistan/Türkiye, 429.

${ }^{130}$ Known as the Emancipation movement in English.

${ }^{131}$ Joost Jongerden and Ahmet Hamdi Akkaya, “The Kurdistan Workers Party and a New Left in Turkey: Analysis of the revolutionary movement in Turkey through the PKK's memorial text on Haki Karer," European Journal of Turkish Studies 14 (2012), accessed July 31, 2020, doi: https://doi.org/10.4000/ejts.4613.

${ }^{132}$ Dilşa Deniz, "1978 yılında sevdiğimiz elimizden alındı: Seyfettin Deniz, Kurtuluş Hareketi ve diğer cinayetler," Dersim Gazetesi, December 30, 2017, accessed July 8, 2020, http://dersimgazetesi.net/tag/seyfettin-deniz/.

${ }^{133}$ Both Kawa and Tekoşin's leaders and members were killed by the state despite Kawa being located in Syria, near the Turkish border. See Joost Jongerden and Ahmet Hamdi Akaya, "Kürdistan Devrimcilerinin İlk Yılları-PKK: Grup Oluşumu, Türkiye Solu ve Kürt Siyasal Partileri ile İlişkiler," academia.edu ([2013] 2015), 479-507, 488-489, accessed July 31, 2020, https://www.academia.edu/13163085/Kurdistan Devrimcilerinin ilk yillari - PKK Grup Olusumu Turkiye Solu ve Kurt Siyasal Partileri ile iliskiler.

${ }^{134}$ Müjgan Halis, "Bir kitap yazd1, 17 yıl yattı," Sabah, March 6, 2011, accessed June 20, 2019, https://www.sabah.com.tr/ pazar/2011/03/06/bir kitap yazdi 17 yil yatti.
} 
Kahraman, a Kurdish intellectual, argues that the Kemalist cadres of the Turkish state founded the Turkish Communist Party (TKP) to obtain financial aid from the Soviet Union. After succeeding, they killed the communists on their way back to the Black Sea. ${ }^{135}$

The state and leftist organizations used rhetoric to mobilize Dersimian youth against their own society that resembled the discourses used during the Dersim military attacks, such as mobilizing around the fight against feudalism. In this fight against feudalism, the state attacked derebeyis, ${ }^{136}$ meaning the aşîret leaders and seyids, before and during the period between 1937 and 1938. The various leftist organizations in the 1970s attacked the very same institutions, the aşirets (axa) and Ocax/seyidship, and similarly defined their struggle as one against the patron-ăg $a$ state. Axaship of the tribe system was crucial for Kurdish ethnic survival, while the Ocax system (seyids) was important for the survival of Alevism. Thus, both together were central to the functioning of the governing body of Kurdish Alevi society in Dersim. While the axaship in Dersim does give the axa some authority in the representation of the tribe, they do not own the land of the tribe, though they do maintain ownership of some personal land. Designated tribal land cannot be sold to anyone outside of the tribe. As such, this system of land ownership does not entail the kind of feudal lordship ${ }^{137}$ that both the Turkish state in the 1930s and leftist organizations in the 70s used in their rhetoric to delegitimize and support attacks on social organization in Dersim. ${ }^{138}$

In addition to attacking the axaship, the seyids, members of a sacred genealogy within the tribes who solved internal disputes, were also portrayed as backward institutions that were inherently opposed to a modern Turkish state. In line with this argument, both leftists and the state were simultaneously pointing out the inferiority of Kurds, who they claimed could not progress and were thus exploited by the axas and seyids, the representatives of "primitive/heretic" religion. This discourse was further invoked by the state to portray the 1938 genocide as an effort to bring civilization to Dersim. Interestingly, this was also the Ottoman's motto: to fight against backwardness and bring civilization to Dersim, as is underlined in the words of Kazim Ateş who pointed out "the continuation between the Abdülhamid period's modernizing concept (in general, 19th Century Ottoman modernism concept) and Kemalist modernism."139

The socialist project was also a project of modernism by the leftist movement and justified itself as necessary to bring socialism and rescue Dersimian from patron-axas' exploitations. ${ }^{140}$ The situation in Dersim was, in fact, better characterized as one of land scarcity, in which no such feudal land ownership system existed to exploit others. In other Sunni regions, where feudal land ownership and exploitation was, in fact, severe, such as in Çukurova, Urfa, Antep, there was no such fight against feudalism by the state, nor did leftist organizations engage in comparable activities. This suggests that these activities were not principally an effort to bring socialism to a region suffering under feudalism, otherwise leftist organizations and the state would have targeted these other regions as well and, perhaps, more aggressively, rather than focusing solely on Dersim and other Kurdish Alevis sites.

In the Dersim case, by contrast, the majority of internationalist leftist movements and the nationalist Turkish state surprisingly shared the same ideas and the same strategy, outlining the seyids and axas as exploiters, and the ones to be fought against. A Turkish sub-lieutenant, Hüseyin Özalp, in memoirs recounting his military service in Dersim, expressed that "the institution of dedeship ${ }^{141}$ which Alevism depended on, was collapsing...[t]he effect of Partizan's ${ }^{142}$ propaganda

\footnotetext{
${ }^{135}$ Ahmet Kahraman, “Şu dünyanın kulpuna bakın siz!," Yeni ÖzgürPolitika, July 2, 2019, accessed July 2, 2019, http:// yeniozgurpolitika.net/su-dunyanin-kulpuna-bakin-siz/.

${ }^{136}$ Derebeyis refers to feudal lords. Baran, Yilları Arasinda Basında Dersim, 209; Uluğ, Derebeyi ve Dersim, 9-10.

${ }^{137}$ Dilşa Deniz, Yol/Rê: Dersim İnanç Sembolizmi, Antropolojik Bir Yaklaşım (Istanbul: İletişim, 2012), 46-47.

138 Ünlü, Turkishness contract, 24.

${ }^{139}$ Kazım Ateş, “Necip Fazıl'ın Dersim'i," Birikim, December 11, 2011, accessed March 7, 2019, https://www.birikimdergisi. com/guncel-yazilar/575/necip-fazil-in-dersim-i\#.XWgYsJNKgnU.

${ }^{140}$ Doğan Munzuroğlu, Toplumsal Yapı ve İnanç Bağlamında Dersim Aleviliği (Ankara: Kalan, 2004), 55.

${ }^{141}$ Another name used for the Seyids.

${ }^{142}$ Partizan was and still is one of the strong leftist organizations in Dersim.
} 
of the years cannot be denied on that matter." ${ }^{143}$ As it is clear, while the leftist aspired towards a socialist revolution, in which neither ethnic nor religious difference existed, ${ }^{144}$ the Turkish state promised to bring civilization exclusively to Dersim, where no feudal exploiters such as the-axas and seyids-would no longer exist. While the leftists promised a socialist country with no ethnic or religious differentiation-in effect rendering Turkishness hegemonic-the state was promising equality after civilization and a process of homogenization that would eventually assimilate the entirety of the population as Muslim Turks.

As argued above, while many leftists and the communist party were supportive of the genocide, later on, many leftist organizations played a significant role in denying the genocide by preventing any connection with ethnicity and religion and glorifying the genocide as an "uprising against the system." As such, Kurdish Alevi youth were successfully led by these organizations to target their own societal structures instead of the nationalist State. Represented as an uprising against the system, without any mention whatsoever of the number of people massacred, the Kemalist/ nationalist cadres were successfully cleared of culpability. Subsequently, leader cadres of the CHP $\mathrm{P}^{145}$ such as Mustafa Kemal (the president, the planner), İsmet İnönü (the Prime Minister) and Fevzi Çakmak (the Chief of General Staff) were not only cleared of their responsibilities in the genocide, but also (and more importantly) were rendered heroes, even saviors of the surviving population. ${ }^{146}$ $\mathrm{CHP}$ was subsequently labelled a progressive party in Turkey and Dersim itself. Mustafa Kemal's portrait hung in Dersimian homes and to this day remain in all Alevi institutions and cemevis. ${ }^{147}$ Streets, schools, hospitals, bridges and neighborhoods were named after the perpetrators: Atatürk, İnönü, and Çakmak. Until the 2000s, when the Kurdish movement was strengthened and allowed to participate in the elections, nearly all of the MPs and mayors of Dersim were elected from the CHP. As such, all of the MPs and mayors further served to absolve and exculpate the perpetrators of their roles in the crimes committed against the people of the city. Genocide thus remains the worst kept secret, while the CHP continues to be labelled a progressive party that many leftists, Alevis, Alevi organizations, and NGOs in Turkey and Dersim have affiliated themselves with. No mention is made of the crimes CHP leaders committed in Dersim or of their involvement in other crimes against non-Turkish and non-Muslim communities. By suppressing their Kurdish and Alevi identity, the Alevi Kurds were able to become members of the party. Thus, many Alevi and Dersim NGOs remain heavily controlled by CHP, which effectively means the support of the TIS ideology.

\section{Conclusion}

The evidence discussed here suggests that the 1937-38 military operations in Dersim clearly meet the criteria to be classified as a genocide according to the $2^{\text {nd }}$ Article of the Genocide Convention. This evidence includes: the long durée (duration) of the preparations and planning that began in the 1930s, the significant military action as represented in the number of soldiers involved and the military equipment employed, ${ }^{148}$ the two-year duration of these events, and, finally the ultimate military directive "to hit anything live." 149 In addition, the assertion of genocide is further supported by estimates that place the number of casualties in the tens of thousands, the number of Dersimian residents subject to forced displacement to the Western cities of Turkey, the thousands of female

\footnotetext{
${ }^{143}$ Hüseyin Özalp, Desim Günlükleri (Ankara: Tanyeri Kitap, 2012), 20.

${ }^{144}$ Munzuroğlu, Toplumsal Yapı, 55.

${ }^{145}$ Cumhuriyet Halk Partisi (Republican People's Party) was founded by M. Kemal and Kemalist cadres in 1923 and was the single ruling party until 1945.

${ }^{146}$ Günday, Adın Perihan Olsun, 134.

${ }^{147}$ Cemevis are Alevis' sites of worship following urbanization.

${ }^{148}$ This equipment included the most advanced technology of the time period such as military aircraft and poison gas.

${ }^{149}$ Sabiha Gökçen, the first women pilot in Turkey who was an Armenian orphan and the god daughter of Mustafa Kemal, in an interview by Halit Kıvanç published in Milliyet on November 25, 1956, noted that they were commanded to hit anything live. Thus, they even hit the goats, which were perceived to be the food of the rebels. Şerıf Karataş, "İnsanları Fare Zehirler Gibi Öldürdüler," Evrensel Gazetesi, May 4, 2012, accessed July 31, 2020, https://www.evrensel. net/haber/28393/insanlari-fare-zehirler-gibi-oldurduler.
} 
children taken from their families and raised by army personnel ${ }^{150}$ to encourage their assimilation, the damage to the city of Dersim and the calculated destruction of her social structures to prevent the survival of the remaining population, the lack of any adequate medical and/or psychological support for orphaned children, the wounded, and all others affected by these devastating events.

It is also clear from both official reports and other documents based on academic writings, news, witnesses' statements, memoirs, and exile literature that the military operations in Dersim between 1937-38 were primarily launched to enact policies of Turkification and Islamization. The UN definition stresses the intention of the crime above its quantitative impact upon the population or its duration. The main aim of these operations is apparent in the legal process that preceded the genocide, such as the Law of Maintaining Order (1925), Resettlement Law (1934), Dersim/ Tunçeli Law (1935), and the related official documents, interviews, official statements made by high-ranking officials.

Due to state-sponsored policies of homogenization, it is clear that at least between forty-six and sixty-three thousand people, including the remaining Armenian population, were killed and more than thirteen thousand Dersimians were forcibly evacuated and resettled in the Western cities of Turkey for the purpose of assimilation. In attempts to justify or deny the large number of casualties and population displacement, media outlets have systematically produced dehumanizing portrayals of residents of the region as bandits and savages participating in an uprising against civilization and state reforms.

The degree of overlapping policies and discourses through which Kurdish ethnicity and Alevi religion were targeted and denied, reveals that the Turkish state exerted significant control over the policies of the leftist movement in Turkey and, particularly in Dersim. Both sides relied upon almost the same discourse, attacked the same structures, and justified their actions as a fight against feudalism only in the Kurdish Alevi regions, where, in fact, no western-type feudalism exists.

Using this same argument, a rhetoric of uprising served as the basis for the denial of the mass killings of unarmed civilians. The state as well as various leftist organizations were hostile to Kurdish leftist organizations that focused on Kurdish identity, forcing them out of Dersim, while others were permitted to remain and co-opted into the state's efforts to suppress Kurdish identity demands and deny the genocide.

Thus, while expunging organizations and persons in favor of Kurdish identity from the region, other organizations, and their discourses were permitted to survive in order to suppress the Kurdish identity. As such, until 1980, the rallying cry in Dersim remained: "[w]e are socialist who are internationalist and atheist [not Kurdish or Alevi]," while, between 1990 and 2000, this slogan became "[w]e are Alevis, and Alevis are not Kurdish," and then between 2000 and 2020, the slogan widely echoed throughout Dersim has been "[w]e are Zaza and Zazas are not Kurdish." Efforts to clear Dersim of Kurdish and Alevi identity through the genocide in 1937-38 have been successfully enacted with devastating consequences but not yet completed. Such efforts continue in the form of ethnocide, culturicide, and ecocide, alongside a denial of the 1937-38 genocide.

\section{Acknowledgements}

I would like to thank my friend and colleague, Nancy Postero, for suggesting the title for this article, and for reading the article and providing me with great feedback. I would also like to thank the Scholar Rescue Fund (IIE-SRF) and Scholar at Risk Network (SAR) for their great support. Thanks to Leanne W. Green and Morgen A. Chalmers for their English language editing.

\section{Dedication}

This article is dedicated to Nuri Dersimi, a Dersimian Kurdish intellectual and politician, who spent his life struggling for Dersim and, as a result, died in exile. Today, he is still helping us understand what took place in Dersim.

\footnotetext{
${ }^{150}$ Gürbey and Gül, Dersim'de Nazi gazı.
} 


\section{Bibliography}

Aday, Nesimi. “Karga Bülbül Olmaz." Dersim Gazetesi, June 27, 2017. Accessed April 4, 2020. http:// nesimiaday.com/index.php/2017/06/27/karga-bulbul-olmaz/.

Agum, Rose Polat. Bego- Dersim 1938 ve Sonrası. Istanbul: Belge, 2018.

Ağar, Ömer Kemal. Tunceli-Dersim Coğrafyası. Istanbul: Türkiye Basımevi, 1940.

Akgül, Suat. Yakın Tarihimizde Dersim Isyanları ve Gerçekler. Istanbul: Boğaziçi, 1992.

Aksoy, Gürdal. "Gas at 'Home,' Gas in the World, On the Use of Poison Gas by the Turkish State in Dersim." Academia.edu, March 7, 2020. Accessed March 18, 2020. https://www. academia.edu/42159488/Yurtta Gaz Cihanda Gaz Tc Devletinin Dersimde Zehirli Gaz Kullanmas\%C4\%B1 \%C3\%9Czerine Gas at Home Gas in the World On the Use of Poison Gas by the Turkish State in Dersim.

Akyürekli, Mahmut. Dersim Kürt Tedibi 1937-1938. Istanbul: Kitapyayınevi, 2012.

Algör, İhami. Ma sekerdo Kardaş? “Dersim 38” Tanıklıkları. Istanbul: Doğan Kitap, 2010.

Arslan, Serhat. "Kürdistan'da Doğa/Ekoloji Katliamı." Toplum ve Kuram: Lêkolîn û Xebatên Kurdî Dergisi 9, (2014), 61-73. Accessed July 7, 2020. http://zanenstitu.org/uploads/dosyalar/ Kitaplar/Toplum\%20ve\%20Kuram/9sayi/Ku\%CC\%88rdistan\%E2\%80\%99da\%20 Dog\%CC\%86a\%20 \%20Ekoloji\%20Katliam\%C4\%B1\%C2\%A0.pdf.

Aslan, Şükrü. "Genel Nüfus Sayımı Verilerine Göre Dersim'de Kayıp Nüfus." In Herkesin Bildiği Sır: Dersim, edited by Şükrü Aslan, 397-412. Istanbul: İletişim, 2010.

Ateş, Kazım. “Necip Fazıl'ın Dersim'i." Birikim, December 11, 2011. Accessed July 3, 2019. https:// www.birikimdergisi.com/guncel-yazilar/575/necip-fazil-in-dersim- i\#.XWqxppNKgnU.

Ayata, Bilgin and Serra Hakyemez. “The AKP's engagement with Turkey's past crimes: an analysis of PM Erdoğan's ‘Dersim apology'." Dialect Anthropology 37 (2013), 131-143. Accessed July 31. Doi: 10.1007/s10624-013-9304-3.

Aydın, Erdoğan. "Ölüm ve Medeniyet Paradoksunda Dersim." Dersim Gazetesi, November 17, 2017. Accessed July 31, 2020. http://dersimgazetesi.net/olum-ve-medeniyet-paradoksundadersim/.

Aydın, Murat. "Dersim“de kimyasal izi ortaya çıktı." CNNTurk, December 4, 2013. Accessed Aygün, Hüseyin. Dersim 38 Resmiyet ve Hakikat. Ankara: Dipnot, 2010.

Baran, Taha. 1937-1938 Yılları Arasında Basında Dersim. Istanbul: Iletişim, 2014.

Barkey, Henri. "Under the Gun: Turkish Foreign Policy and the Kurdish Question." In The Kurdish Nationalist Movement in the 1990s: Its Impact on Turkey and the Middle East, edited by Robert Olson, 65-83. Kentucky: The University Press of Kentucky, 1996.

Bedrosyan, Raffi. "Dersim: A First Step in Facing the Past in Turkey." The Armenian Weekly, December 1, 2011. Accessed April 4, 2020. https://armenianweekly.com/2011/12/01/dersima-first-step-in-facing-the-past-in-turkey/.

Beşikçi, İsmail. Tunceli Kanunu (1935) ve Dersim Jenosidi. Istanbul: Belge, 1990.

Beyazgazete. "12 Eylül'ün acıları yetmedi mi? Irkçı afişten sonra darbe çağrısı." Beyazgazete, February 2, 2012. Accessed April 8, 2020. http://beyazgazete.com/haber/2012/2/2/12-eylulun-acilari-yetmedi-mi-irkci-afisten-sonra-darbe-cagrisi-1038130.html.

Bozarslan, Hamit. "Political Crisis and the Kurdish Issue in Turkey." In The Kurdish Nationals Movement in the 1990s, Its Impact on Turkey and the Middle East, edited by Robert Olson, 135153. Kentucky: The University Press of Kentucky, 1996.

Bulut, Faik. Dersim Raporları. Istanbul: Evrensel Basım Yayım, 2009.

Çağlayangil, Ihsan Sabri. “Çağlayangil: Ordu Dersim Kürtlerini Kesti, Fare Gibi Zehirledi!” T24, November 19, 2011. Accessed July 9, 2020. https://t24.com.tr/haber/caglayangil-ordudersim-kurtlerini-kesti-fare-gibi-zehirledi,182465

Çem, Munzur. Dersim Merkezli Kürt Aleviliği. Istanbul: Vate, 2010.

------. Qurzeli Usiv'in 70 Yalı. Istanbul: İletişim, 2014.

Demir, Hasan. Dersim'den Tunceli'ye 38 Katliamı Tanıklikları. Istanbul: Belge, 2011.

Deniz, Dilşa. Yol/Rê: Dersim İnanç Sembolizmi, Antropolojik Bir Yaklaşım. Istanbul: İletişim, 2012.

--------- "Dersim'in Ekonomi Politiği İçinde Talanın Yeri: Antropolojik Bir Yaklaşım." In Dört Dă̆a Sığmayan Kent, Dersim Üzerine Ekonomi-Politik Yazılar, edited by Şerif Gürçağ Tuna and Gözde Orhan, 71-111. Istanbul: Patika Kitap, 2013. 
---------. “1978 yılında sevdiğimiz elimizden alındı: Seyfettin Deniz, Kurtuluş Hareketi ve diğer cinayetler." Dersim Gazetesi, December 30, 2017. Accessed July 8, 2020. https:// dersimgazetesi.org/seyfettin-deniz/.

--------.. "Kurdish Alevi Belief System, Reya Heqi/Raa Heqi, Structure, Networking, Ritual, and Functions." In Kurdish Alevis and the Case of Dersim, Historical and Contemporary Insights, edited by Erdal Gezik \& Kerim Gültekin, 45-73. London: Lexington, 2019.

Dersimi, Nuri. Kürdistan Tarihinde Dersim. Diyarbakır: Dilan, 1992.

Fındık, Özgür. Kara Vagon, Dersim-Kırım ve Sürgün. Istanbul: Fam, 2012.

------. "Kara Vagon - 38 Dersim Sürgünleri." Aired May 4, 2011. Can TV. YouTube video, 01:06:39. Uploaded December 6, 2018. Accessed March 8, 2020. https://www.youtube.com/ watch?v=ao- qvFXcVg.

Firat Development Agency. Tunceli, December31, 2013. Accessed June 13, 2019. http://investintunceli. gov.tr/tr/files/rakamlarla-tunceli.pdf.

Gazetesi, Dersim. “Zehirli Gazlar Nazi Almanyası'ndan Alınmış!” Dersim Gazetesi, May 15, 2019. Accessed July 8, 2020. http://dersimgazetesi.net/zehirli-gazlar-almanyadan-bombardimanucaklari-amerikadan-alinmis/.

Günday, Fatma Betül. "Adın Perihan Olsun" Diyap A ̆̆a'nın Torunu Ane Hatun'un Hikayesi. Istanbul: Iletişim, 2016.

Gündoğan, Nezahat, and Kazım Gündoğan. Desrim'in Kayıp Kızları. Istanbul: Iletişim, 2016.

Gürbey, Hüsnü and Mahsuni Gül. "Dersim'de Nazi Gazı". Rojnameya Newroz, May 16, 2019. Accessed April 4, 2020. http://rojnameyanewroz2.com/dersimde-nazi-gazi-h-gurbey-mgul-14583.html.

Jongerden, Joost and Ahmet Hamdi Akkaya. "The Kurdistan Workers Party and a New Left in Turkey: Analysis of the revolutionary movement in Turkey through the PKK's memorial text on Haki Karer." European Journal of Turkish Studies 14, (2012). Accessed July 31, 2020. Doi: doi.org/10.4000/ejts.4613

. "Kürdistan Devrimcilerinin İlk Yılları-PKK: Grup Oluşumu, Türkiye Solu ve Kürt Siyasal Partileri ile İlişkiler." Academia.edu ([2013] 2015), 479-507. Accessed July 7, 2020. https:// www.academia.edu/13163085/Kurdistan Devrimcilerinin ilk yillari - PKK Grup Olusumu Turkiye Solu ve Kurt Siyasal Partileri ile iliskiler.

Halis, Müjgan. "Bir kitap yazdl, 17 yıl yattı." Sabah, March 6, 2011. Accessed June 20, 2019. https:// www.sabah.com.tr/pazar/2011/03/06/bir kitap yazdi 17 yil yatti.

Hallı, Reşat. Türkiye Cumhuriyetinde Ayaklanmalar (1924-1938). Ankara: Genelkurmay Basımevi, 1972.

İnce, Gökçen, Başaran. "Zamanında Dersim Nasıl Haber Olmuştu?" Birikim, December 15, 2011. Accessed July 30, 2020. https://www.birikimdergisi.com/guncel/577/zamaninda-dersimnasil-haber-olmustu.

International Foundation for Electoral Systems. Elections in Turkey: 2019 Local Elections: Frequently Asked Questions. Washington DC: Middle East and North Africa: International Foundation for Electoral Systems, March 25, 2019, 1-8. Accessed July 31, 2020. https://www.ifes.org/ sites/default/files/2019 ifes turkey local elections faqs final.pdf.

Iskân Kanunu (Turkish Resettlement Law) of 1934 (Law No. 2510, June 21, 1934). (Rep. of Turkey). Accessed July 31, 2020. https://resmigazete.gov.tr/arsiv/2733.pdf.

Jandarma Umum Komutanlığı Raporu (JUK). Istanbul: Kaynak, [1932] 2010.

Kahraman, Ahmet. "Şu dünyanın kulpuna bakın siz!" Yeni Özgur Politika, July 2, 2019. Accessed July 2, 2019. http://yeniozgurpolitika.net/su-dunyanin-kulpuna-bakin-siz/.

Karataş, Şerıf. “İnsanları Fare Zehirler Gibi Öldürdüler.” Evrensel Gazetesi, May 4, 2012. Accessed July 31, 2020. https://www.evrensel.net/haber/28393/insanlari-fare-zehirler-gibi-oldurduler.

Kaynak Yayınları, Genelkurmay Belgelerinde Kürt İsyanları II. Istanbul: Kaynak Yayınları, 2011

Kendal. "Kurdistan in Turkey." In People Without A Country, The Kurds and Kurdistan, edited by Gerard Chaliand, translated by Michael Pallis, 47-106. London: Zed, 1980.

Kieser, Hans-Lukas. “Dersim Massacre, 1937-1938." Online Encyclopedia of Mass Violence, July 27, 2011. Accessed April 5, 2019. https://www.sciencespo.fr/mass-violence-war-massacreresistance/en/document/dersim-massacre-1937-1938. 
Kısakürek, Necip Fazıl. Son Devrin Mazlumlari. Istanbul: Büyük Doğu Yayınları, 1969.

Lemkin, Raphaël. Axis Rule in Occupied Europe: Laws of Occupation, Analysis of Government, Proposals for Redress. Washington: Carnegie Endowment for International Peace, 1944.

Morris, Benny and Dror Ze'evi. The Thirty-year Genocide, Turkey's Destruction of its Christian Minorities 1894-1924. Massachusetts: Harvard University Press, 2019. Doi: $10.4159 / 9780674240070$

Munzuroğlu, Doğan. Toplumsal Yapı ve İnanç Bağlamında Dersim Aleviliği. Ankara: Kalan, 2004.

NordNordWest. "Dersim region in the mid 1930s, English version." GTOPO-30 Elevation Data by USGS, United States National Imagery and Mapping Agency data, March 13, 2009. Accessed August 19, 2020. https://en.wikipedia.org/wiki/Dersim rebellion\#/media/ File:Dersim region in the mid 1930s English.png.

Oran, Baskin. "1938 Dersim: Bir belge de Nazimiye Nüfus Müdürlügü̈’nden!” Radikal, August 29, 2014. Accessed July 29, 2019. http://www.radikal.com.tr/yazarlar/baskin-oran/1938dersim-bir-belge-de-nazimiye-nufus-mudurlugunden-1209663/.

--------. "Ulus Devlet ve Dersim." In 1. Uluslararası Tunceli (Dersim) Sempozyumu Bildiriler, edited by Hıdır Özdemir, Ali Kemal Özcan, Candan Badem, Sabit Menteşe, Bayram Güneş, Murat Cem Demir, XXIII-XXVII. Tunceli: Tunceli Universitesi, 2010.

Öz, Baki. Dersim Olayı. Istanbul: Can, 2004.

Özalp, Hüseyin. Desim Günlükleri. Ankara: Tanyeri Kitap, 2012.

Pirha. "Dersim Katliamı Ile Ilgili Yeni Belgeler Ortaya Çıktı: Dersim'de Nazi Gazları." May 11, 2019. Accessed July 7, 2020. https://www.pirha.net/dersim-katliami-ile-ilgili-yeni-belgelerortaya-cikti-dersimde-nazi-gazlari-171973.html/11/05/2019/.

Sağlam, Hasan. Topră̆ına Tutunanlar-Yasak Mintıkanın Çocukları II. Istanbul: Totem, 2018.

---.. Yasak Mintıkanın Çocukları. Istanbul: Totem, 2015.

Şimşir, Bilal N. İngiliz Belgeleriyle Türkiyesde Kürt Sorunu: (1924-1938): Şeyh Sait, Ağrı, ve Dersim Ayaklanmaları. Ankara: Türk Tarih Kurumu Basımevi, 1991.

Stanton, Gregory. "The Ten Stages of Genocide." Genocide Watch. Accessed July 6, 2020. https:// www.genocidewatch.com/ten-stages-of-genocide.

T24, “Başbakan: Tunceli'de kendi halkına karşı kullanılan zehirli gaz düşmana bile uygulanamaz, utanç duyuyorum!." November 19, 2014. Accessed September 7, 2019. https://t24.com. tr/haber/basbakan-tuncelide-kendi-halkina-karsi-kullanilan-zehirli-gaz-dusmana-bileuygulanamaz-utanc-duyuyorum,277596.

Taş, Cemal. Dağların Kayıp Anahtarı-Dersim 1938 Anlatıları. Istanbul: Iletişim, 2011.

Takrir-i Sükun Kanunu (Law of Maintenance of Order) of 1925 (Law No. 578, March 4, 1925). TBMM Tutanakları. (Rep. of Turkey). Accessed July 27, 2020. https://www.tbmm.gov.tr/tutanaklar/ KANUNLAR KARARLAR/kanuntbmmc003/kanuntbmmc003/kanuntbmmc00300578. pdf.

Tunçeli Vilâyetinin Idaresi Hakkında Kanun (Law of the Administration of City of Tunceli) of 1935 (Law No.2884, January 2, 1936). (Rep. of Turkey). Resmi Gazete. Accessed July 7, 2020. https://www.resmigazete.gov.tr/arsiv/3195.pdf.

Türkyılmaz, Zeynep. "Maternal Colonialism and Turkish Woman's Burden in Dersim: Educating the 'Mountain Flowers' of Dersim." Journal of Women's History 28, no. 3, (2016), 162-86. Accessed July 7, 2020. Doi: 10.1353/jowh.2016.0029

--------. “Dersim Soykırımı ve 'Kötülüğün Sıradanlığı.” Agos, November 11, 2019. Accessed March 8, 2020, http://www.agos.com.tr/tr/yazi/23286/dersim-soykirimi-ve-kotulugun-siradanligi.

Uluğ, Naşit Hakkı. Derebeyi ve Dersim. Istanbul: Kaynak, 2009.

United Nations. General Assembly Resolution 260, Convention on the Prevention and Punishment of the Crime of Genocide. December 9, 1948. UN Doc. A/Res/260(III).

Ünlü, Barış. “Kürdistan/Türkiye ve Cezayir/Fransa: Sömürge Yöntemleri, Şiddet ve Entellektüeller.” In Türkiye'de Siyasal Şiddetin Boyutları, edited by Güney Çeğin and İbrahim Şirin, 403-34. Istanbul: Iletişim, 2014.

. "'Turkishness contract' and Turkish left." Perspectives: Political analysis and commentary from Turkey, no. 3.13, edited by Ulrike Dufner, Özgür Gürbüz, Semahat Sevim, Yonca Verdioglu, 23-27. Istanbul: Henrich Böll Stiftung, December 2012. Accessed July 31, 2020. https://www. boell.de/sites/default/files/perspectives turkey 3 eng.pdf. 
van Bruinessen, Martin. "Genocide in Kurdistan? The Suppression of the Dersim Rebellion in Turkey (1937-38) and the Chemical War Against the Iraqi Kurds (1988)." In Conceptual and Historical Dimensions of Genocide, edited by George J. Andreopoulos, 141-170. Pennsylvania: University of Pennsylvania Press, 1994

Yağan, Emirali. Dersim Defterleri - Beyaz Dă̆'da Bir Gün. Istanbul: Iletişim, 2013.

Yeşiltuna, Serap. Devletin Dersim Arşivi. Istanbul: İleri Yayınları, 2012.

Yıldız, Celal. Dersim Dile Geldi-Dersim Otuz Sekiz'in Çocukları Konuştu. Ankara: Nika, 2012.

Zürcher, Erik J. Turkey: A Modern History. London, New York: I.B. Tauris, 2017. 